\title{
Protection of the Right to Freedom of Assembly under Ethiopian Law: Gaps and the Way Forward
}

\section{Abstract}

Tsega Andualem Gelaye *

The right to Freedom of assembly is among the political rights enshrined under the Constitution of the Federal Democratic Republic of Ethiopia (FDRE). Despite the frequent reporting of its rampant violation by human right monitoring bodies and the media, one cannot find a research that assesses the adequacy of protection offered to the right by the Ethiopian Constitution and other laws of the country. This article seeks to fill this gap by indicating some of the key problems with the existing legal regime governing the right and the prevailing practice. As such, it argues that the present Constitution of Ethiopia gives an incomplete protection to the right, by failing to go beyond listing grounds of limiting it without incorporating additional guarantees of preventing arbitrary restrictions such as necessity and proportionality in explicit manner. Moreover, it contends that this problem was exacerbated by the presence of too many loopholes in the Peaceful Demonstration and Public Political Meetings Proclamation that ranges from inadequate rules governing notification procedure to the absence of fair hearing and judicial or administrative review procedures in the law. Suggestions to improve the legal guarantees for freedom of assembly in Ethiopia are also made in the article in light of lessons from the experience of other national and international jurisdictions with better standards of protection. Furthermore, it asserts that reforming the legal regime applicable to freedom of assembly and ensuring its appropriate implementation requires a strong political will of the ruling party in promoting good governance, respecting rule of law and strengthening democratic institutions.

\section{Key terms}

Demonstration, Ethiopia, freedom of assembly, notification, proportionality, limitation

DOI http://dx.doi.org/10.4314/mlr.v10i2.2

\footnotetext{
* Tsega Andualem Gelaye, LL.B, LL.M in Human Rights Law (Addis Ababa University), LL.M in Comparative Constitutional Law (Central European University), (SJD student in Comparative Constitutional Law, Central European University). The author would like to thank the anonymous reviewers of the Journal for enhancing the quality of the final article. He could be reached at: tsega.andualem@gmail.com
} 


\section{Introduction}

Freedom of assembly is a right that is rarely defined in major human rights treaties including the International Covenant on Civil and Political Rights (ICCPR). No General Comment that defines what the right protects is issued to date. To fill this gap in the existing treaties, several authorities have attempted to define what is meant by protected assembly. For instance, the experts of the Venice Commission (an advisory body of the Council of Europe) have defined an assembly as 'Intentional and temporary presence of a number of individuals in a public place for a common expressive purpose'. ${ }^{1}$ The right safeguards the purposeful gathering of people in public places such as streets, parks, squares or other spaces that are freely accessible to the public. The ultimate aim of such gathering is the public expression of positions on various issues of public concern, be it in a declarative form like the case of public demonstration or an inward deliberation and discussion on issues among the assembled as the case in public meetings. $^{2}$

The right to freedom of assembly only safeguards gatherings which are nonviolent. ${ }^{3}$ This requirement is implied in every definition of a protected assembly and unanimously recognized in international human rights instruments as well as the domestic constitutions of states. Here it must be noted that, the right to freedom of assembly is not an absolute right. Thus, limitations could be placed upon it to safeguard other legitimate interests such as national security, public safety, public order or respect for the rights of others. ${ }^{4}$ This however does not mean that the right could be restricted arbitrarily by invoking every ground. Instead, 'in each instance of potential limitation the state must clearly define the precise purpose served, as well as showing that the measure in question is necessary and proportionate'. 5 In other words, the state must meet the proportionality scrutiny.

${ }^{1}$ OSCE/ODHIR (2010), Venice Commission Guideline on Freedom of Assembly (2 ${ }^{\text {nd }}$ ed) (June 2010).

${ }^{2}$ O. Salat (2015), The Right to Freedom of Assembly a Comparative Study, Hart, Oxford, pp. 5-6.

${ }^{3}$ OSCE/ODHIR (n1), pp. 25-26.

${ }^{4}$ International Covenant on Civil and Political Rights Adopted and opened for signature, ratification and accession by General Assembly resolution 2200A (XXI) of 16 December 1966, entry into force 23 March 1976, in accordance with Article 49) art. 21; African (Banjul) Charter on Human and Peoples' Rights, (Adopted 27 June 1981, OAU Doc. CAB/LEG/67/3 rev. 5, 21 I.L.M. 58 (1982), entered Into Force 21 October 1986, art. 11.

${ }^{5}$ African Commission on Human and Peoples Right (ACHPR), Report of the Study Group on Freedom of Association \& Assembly in Africa, (2014), p.21. 
Like many national constitutions, the present constitution of Ethiopia (FDRE Constitution) adopted in 1995 has recognized the right to freedom of assembly. ${ }^{6}$ Ethiopia has also ratified all international and regional treaties acknowledging this right which further reinforces its obligation to respect and enforce it. Moreover, other subsidiary laws were enacted prior to the adoption of the Constitution with the objective of facilitating the implementation of the right. ${ }^{7}$ Yet, the right remains one of the most repressed political rights in the country as witnessed in practice. Severe suppression of the right has led some including the author, to regard the right as illusory and devoid of any practical significance.

To corroborate this assertion, it might be relevant to see the situation in the pre and post 2005 Ethiopian general election. This period is imperative for anyone who is interested in studying the history of freedom of assembly in Ethiopia since the adoption of the Constitution in 1995. It marks the period where, the right enjoyed a relative respect for a short duration before it entered its several years of hibernation. Unlike the preceding elections which were largely boycotted, the 2005 election was competitive to a large extent. ${ }^{8}$ This is mainly attributed to the pledge of the ruling party to open democratic space and undertake a free and fair election. ${ }^{9}$ Accordingly, 'live televised debates on matters of public policy, opposition party access to state-owned media, and huge, peaceful rallies' were seen for the first time ${ }^{10}$ Further, in a manner which is unprecedented before, nearly one million people in the capital displayed their support for opposition parties through an entirely peaceful demonstration. ${ }^{11}$ Other massive rallies were also held by opposition supporters in many parts of the country without much difficulty.

However, these developments were short-lived. On the evening of the election date, the late prime minster issued a decree that outlaws the conducting of demonstration in the capital for a period of one month which was extended

\footnotetext{
${ }^{6}$ The Federal Democratic Republic of Ethiopia Constitution (1995), art. 30(1).

7 The Proclamation to Provide for Peaceful Demonstration and Public Political Meetings, Proclamation No. 3/1991, Federal Negarit Gazzeta 50th Year No. 4, Addis Ababa, 12 August 1991 (hereinafter Demonstration and Political Meeting Proclamation).

${ }^{8}$ Terrence Lyons, 'Ethiopia in 2005: The Beginning of a Transition?' African Notes No.25 Center for Strategic and International Studies January $2006<\mathrm{https}: / / \mathrm{csis}-$ prod.s3.amazonaws.com/s3fs-public/legacy_files/files/media/csis/pubs/anotes_0601.pdf > accessed on 23 October 2016.

${ }^{9}$ Ibid.

${ }^{10}$ Ibid.

${ }^{11}$ Stefan Brüne (2010), 'The European Union and its Africa strategy Case study Ethiopia' in Valeria Bello and Behailu Geberewold (eds)A Global Security Triangle European, African and Asian Interaction, Routledge Taylor Francis Group, London and New York, p.142.
} 
until July 2005. ${ }^{12}$ Those who defied the order of the prime minster paid dearly with their lives and bodies. Even after the expiry of the ban on demonstration, in September and subsequent months, municipalities and other administrative units consistently refused to allow gatherings organized by opposition parties in different parts of the country. ${ }^{13}$ This marked the beginning for the long period of dormancy for the right. Thus, for eight years subsequent to the 2005 controversial election, no demonstration was held in the capital Addis Ababa. ${ }^{14}$

Even after 2013, a number of notifications for undertaking public demonstrations or political meetings were either denied by the authorities regulating assemblies from the very outset or dispersed by force subsequently. ${ }^{15}$ Many people also died and sustained bodily injury in the course of exercising this right in Oromia and Amhara regional states of Ethiopia. ${ }^{16}$ The violence and destruction of property that ensued following the crackdown of the protests by security personnel ultimately led to the declaration of state of emergency ${ }^{17}$ by the government which entailed the complete suspension of the right to freedom of assembly and severe restrictions to other fundamental freedoms throughout

${ }^{12}$ Carter Center, Observing The 2005 Ethiopia National Elections Carter Center Final Report (December 2009) p.4.

${ }^{13}$ U.S Department of State, 'Ethiopia' (8 March 2006). $<\mathrm{http}: / /$ www.state.gov/j/drl/rls/hrrpt/2005/61569.htm> accessed on 21 October 2016.

${ }^{14}$ Solomon Goshu, 'Peaceful Political Rallies: The Right Besieged by Hurdles', The Reporter, 31 January $2015<$ http://allafrica.com/stories/201502020437.html> accessed 31 March 2016; Human Right Watch, World Report 2015: Ethiopia, $<$ https://www.hrw.org/world-report/2015/country-chapters/ethiopia> accessed on 27 May 2016.

${ }^{15}$ Neamin Ashenafi, 'Cancellation of Planned Demonstration Annoys Medrek' $<\mathrm{http}: / / \mathrm{www}$.thereporterethiopia.com/content/cancellation-planned-demonstration-annoysmedrek> accessed 1April 2016; 'Ethiopia Arrests 43 Anti-Graziani Statute Protesters in Addis Ababa' <http://www.awrambatimes.com/?p=13407> accessed 31 March 2016, Ethiopian Police Crackdown On Anti-Saudi Protest'.

$<$ http://bigstory.ap.org/article/ethiopian-police-crackdown-anti-saudi-protest $>$ accessed 31 March 2016.

16 'UN Experts Urge Ethiopia To Halt Violent Crackdown On Oromia Protesters, Ensure Accountability For Abuses'

$<$ http://www.ohchr.org/en/NewsEvents/Pages/DisplayNews.aspx?NewsID=16977\&LangI $\mathrm{D}=\#$ sthash.veMqExX4.dpuf $>$ accessed 1 April 2016; 'Ethiopia: Dozens killed as Police Use excessive force against peaceful Protesters'

$<$ https://www.amnesty.org/en/latest/news/2016/08/ethiopia-dozens-killed-as-police-useexcessive-force-against-peaceful-protesters/? > accessed on 18 November 2016;'Dozens killed in Ethiopia protest crackdown' <http://www.aljazeera.com/news/2016/08/30-killedethiopia-protests-opposition-160808105428331.html> accessed on 18 November 2016.

17 'Ethiopia declares state of emergency as deadly protests continue' The Guardian (10 October 2016) <https:/www.theguardian.com/world/2016/oct/10/ethiopia-declares-stateof-emergency-as-deadly-protests-continue> accessed: 18 November 2016. 
the country. Further, more than 11,000 people were arrested by the Ethiopian government 'command post' subsequently for their alleged involvement in violence and destruction of property. ${ }^{18}$ According to the Ethiopian Broadcasting Corporation, 9,980 detainees were expected to be released until the end of December 2016 (EBC; December 17, 2016).

This article seeks to critically assess the contribution of the existing Ethiopian legal regime governing freedom of assembly for this state and its adequacy from a comparative perspective. Accordingly, the first section explores the rationale for protecting freedom of assembly by pointing certain features and functions that distinguishes it from other rights. The second section examines the protection of the right under the FDRE Constitution by focusing on limitations. Sections 3 to 7 analyze the provisions of the Ethiopian Peaceful Demonstration and Public Political Meeting proclamations by giving emphasis to issues of notifications, spontaneous assemblies, restrictions on time, place and conduct, public order and public safety limitations, hearing procedure and judicial review. These aspects would be critically examined in the light of selected practices and cases in a comparative manner. The last section assesses the importance of political will of those in power towards promoting good governance, rule of law and strengthening democratic institutions to address the problems identified in the legal regime and its implementation.

\section{The Utility of Freedom of Assembly}

Given the strong interlink between the right to freedom of expression and the right to freedom of assembly, some question whether the latter adds any unique value. Concerning the relation between the two sets of rights, one must underscore the undisputed fact that any form of assembly ultimately has a communicative or expressive purpose. As such, the expression aspect of freedom of assembly is within the purview of protection of the right to freedom of expression ${ }^{19}$ because demonstration and meeting constitute one of the mechanisms available for disseminating one's view. This has led some to contend that if the ultimate objective of freedom of assembly is 'expression', individuals should utilize other options of communicating their concerns through the mass media including news papers, radio, TV or internet. ${ }^{20}$ The justification they offer in support of their contention is that, since ordinary

\footnotetext{
18 'Ethiopia state of emergency arrests top 11,000'

$<$ http://www.aljazeera.com/news/2016/11/ethiopia-state-emergency-arrests-top-11000161112191919319.html $>$ accessed 18 November 2016.

${ }^{19}$ Manfred Nowak et al (eds) (2012), All Human Rights for All: Vienna Manual on Human Rights, Antwerp: Intersentia; Vienna : NW Verlag Recht, p.382.

${ }^{20}$ Eric Barendt (2000), 'Freedom of Assembly', Chapter 9 in Jack Beatson and Yvonne Cripps(eds.), Freedom of Expression and Freedom of Information, OUP, p.161.
} 
assemblies create inconvenience for the public by disrupting the flow of traffic and operation of businesses, individuals should resort to less disruptive channels of communication. ${ }^{21}$

What such critics ignore is that, expression through mass media is qualitatively different from physical assemblies. By virtue of their physical presence together in public places, the latter indicate how committed and united they are for the cause they stand for which has the capacity to exert influence on the government. ${ }^{22}$ Further, the dramatic nature of expression also enables participants to express their position in a vivid and influential manner. Moreover, all sections of the society do not have equal access to various means of communication because of poverty or marginalization. Hence, 'freedom of assembly provides opportunities for public expression of those with less power, wealth or status. ${ }^{23}$ In particular, freedom of assembly guards the rights of the minorities from the tyranny of the majority. Any democratic system aspires to rule/implement the wishes of the majority of the people while protecting the rights of the minorities. Freedom of assembly pursues this aspiration of democracy by allowing minorities to assemble together and voice their concerns and interests. ${ }^{24}$ At times, freedom of assembly could be the only way to make their voice heard since they do not have the power to influence the political process using the normal system of election since they would be outnumbered. It would also enhance their right to self determination enabling them to promote their culture, way of living and identity. ${ }^{25}$

An assembly is primarily 'characterized by physical presence of multitude of individuals who are aligned by a common purpose to collectively communicate $a$ cause to the general public [emphasis added] ${ }^{26}$ What made the collective expression of concern possible in the first place is physical gathering of many individuals with a shared interest. Hence, what an assembly distinctly safeguards is the 'bodily togetherness of a group of people' ${ }^{27}$ In the absence of the right to freedom of assembly, individuals could not gather in the first place for voicing matters affecting public interest. And this attribute is not addressed by freedom of expression.

${ }^{21}$ Id., 164.

${ }^{22}$ Id., 166.

${ }^{23}$ N. Jarman and M. Hamilton (2009), "Protecting peaceful protest: The OSCE/ODHIR and Freedom of Peaceful Assembly" Journal of Human Rights Practice Vol.1 No.2 (2009), p. 208.

${ }^{24}$ Solyom Peter (tras) (2008), 'The Constitutional Principles of Freedom of Assembly in Hungary', Fundamentum Vol.12, p.37.

${ }^{25}$ OSCE/ODHIR supra note 1, p.13.

${ }^{26}$ Michel Rosenfeld and András Sajó (ed) (2012), The Oxford Handbook of Comparative Constitutional Law, Oxford University Press, p.951.

${ }^{27}$ Ibid. 
The underlying goal of the two rights is different. Freedom of expression is characterized by some scholars as civil right primarily because its prime focus is to allow the individual fulfill himself by speaking his mind. ${ }^{28}$ The 'discovery of truth' through the exchange of different ideas is also mentioned as an additional aim of the right. ${ }^{29}$ In contrast, the right to freedom of assembly is characterized as political right since its principal target is the governing of the polity and democratic process. ${ }^{30}$ Hence, assemblies primarily promote collective interests rather than individual ones. Besides, the contribution of assemblies for discovery of truth is also minimal since the prime concern of the participants in a demonstration is not discovering the truth but making their voice heard and taking a position. ${ }^{31}$

Freedom of assembly is also regarded as an 'early warning' instrument for democracies that something is going wrong with the system. ${ }^{32}$ Protests against the government expressed in the form of demonstration would indicate that some sections of the society are seriously dissatisfied with the way the government is handling certain matters. In a democratic system, governments are expected to be responsive to the demands of the people. ${ }^{33}$ As such, when the people express their displeasure, the government must seriously consider those issues and address them properly before they are exacerbated. Ignoring the early warning might make it difficult for the government to handle issues after they go out of control.

\section{Freedom of Assembly under the Ethiopian Constitution}

The FDRE Constitution provides that all persons have the 'right to assemble' 'to demonstrate' and 'to petition'. ${ }^{34}$ The fact that the Constitution does not define each of these terms might not be surprising given the nature of constitutions that merely enshrine general principles. It is to be noted that the prevailing literature characterizes them as different forms of assembly. The 'right to assemble' in the Constitution primarily refers to public meetings conducted with the purpose of deliberating on certain important matters. ${ }^{35}$ This could be contrasted with the 'right to demonstrate' that has the principal objective of proclaiming the position of the assembled on an essential matter to the external audience

\footnotetext{
${ }^{28}$ Nowak, supra note 19, p. 371.

${ }^{29}$ Barendt, supra note 20, p. 166.

${ }^{30}$ Nowak, supra note 19, p. 371 .

${ }^{31}$ Barendt supra note 20, p.166.

${ }^{32}$ Salat, supra note 2, pp.49-50.

${ }^{33}$ Ibid.

${ }^{34}$ FDRE Constitution, supra note 6, art 30(1).

${ }^{35}$ Salat, supra note 2, p.6.
} 
concerned. $^{36}$ Hence, the target of demonstration is getting attention of an outsider rather than discussing the issue among the assembled.

This line of interpretation also conforms to the stipulations of the Proclamation on Peaceful Demonstration and Public Political Meeting ${ }^{37}$ which serves as the implementing legislation in Ethiopia for the constitutional provision that enshrines the right to freedom of assembly. Accordingly, the Proclamation makes a distinction between 'peaceful demonstration' and 'public political meeting' and defines them separately. By peaceful demonstration the Proclamation refers to 'any public and orderly procession in which a group of people express their ideas through speech, songs, mottos, placards etc... [emphasis added]'. ${ }^{38}$ This definition fits to the declaratory nature of demonstrations. The usage of symbols, songs and placards is also a distinguishing feature of such gatherings. With respect to 'public political meetings' the Proclamation explicates its meaning in the following manner 'any meeting in which a group of people discuss political and politics oriented issues [emphasis added]'. ${ }^{39}$ From this, one can observe that the focus of political meetings is more on deliberation and discussion than expression of stance.

The tricky part in the Ethiopian constitutional provision recognizing freedom of assembly is the 'right to petition'. Does it provide something which is not covered either by right to assembly or demonstration? Or is it a needless duplication? To address these questions, we can examine the interpretation given to such formulations in early constitutions that included the right to assemble and the right to petition in the same provision. A good example in this regard is the First Amendment of the US Constitution adopted in 1791. It provides: 'Congress shall make no law ... abridging ... the right of the people peaceably to assemble, and to petition the Government for a redress of grievances ${ }^{40}$.

According to El-Haj, the framers of the US Constitution saw a strong intersection between the two sets of right, and that explains why they paired them. ${ }^{41}$ He states that some of the founders of the Constitution argued that in the normal course of things, submission of grievances by the public to the government are preceded by the assembly of the people to seriously deliberate on the issue and it is only logical to place the two rights together. However, it is important to note that not all assemblies have the ultimate purpose of

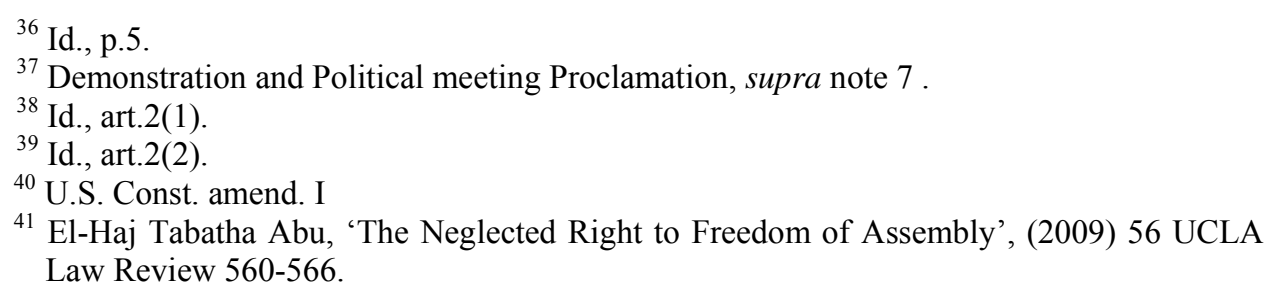


communicating discontent or petition. They might be convened for deliberation or celebratory purpose. Likewise, the right to petition is not necessarily tied to the right to freedom of assembly since protest could be expressed by using various channels of communication without the need to assemble.

The same logic can explain the pairing of the right to freedom of assembly with the right to petition under the Ethiopian Constitution. Hence, it could be argued that the Constitution made reference to the right to petition in this provision in order to underscore that the right to freedom of assembly or demonstration is not only confined to mere deliberation on an issue or demonstration. Rather, it could go to the extent of demanding the government to address their grievances deliberated and expressed through demonstration. As such, the presence of the right to petition in the provision (that recognizes freedom of assembly) further enhances the exercise of the right to assembly by explicitly informing the people about their entitlement to express their dissatisfactions with the measures or actions of the government and demand redress by using demonstration as a channel.

The Constitution also lists the grounds for limiting freedom of assembly which includes 'public convenience', 'protection of democratic rights', 'public morality' and 'peace'. ${ }^{42}$ The terms 'public convenience' and 'democratic rights' are somewhat unique. This is because it is uncommon to find such kind of formulations in other jurisdictions. For instance, 'national security or public safety, public order (ordre public), the protection of public health or morals or the protection of the rights and freedoms of others' are mentioned as the only possible reasons for restricting the right under the ICCPR. ${ }^{43}$ These grounds are often addressed in human rights literature and jurisprudence of courts as 'legitimate aims' for restricting a right. With respect to public safety, it refers to safeguard 'against danger to the safety of the persons, their life or physical integrity, or serious damage to their property. ${ }^{44}$

The ground 'public order' is more tricky because of its relative broadness. According to the Siracusa Principles, 'public order' refers to 'sum of rules which ensure the functioning of the society or set of fundamental principles on which the society is founded. ${ }^{45}$ The FDRE Constitution seems to allow the consideration of 'public convenience' as a ground for restricting the venue and

\footnotetext{
${ }^{42}$ FDRE Constitution, supra note 6 , art 30(1).

${ }^{43}$ International Covenant on Civil and Political Rights Adopted and opened for signature, ratification and accession by General Assembly resolution 2200A (XXI) of 16 December 1966, entry into force 23 March 1976, in accordance with Article 49) art. 21.

${ }^{44}$ Siracusa Principles on the Limitation and Derogation of Provisions in the International Covenant on Civil and Political Rights (hereinafter Siracusa Principles) Annex, UN Doc E/CN.4/1984/4 (1984) art vii para.33.

${ }^{45}$ Id., para. 22.
} 
route for conducting an assembly or a demonstration. In its essence, the ground resembles 'public order' stipulated under the ICCPR since its ultimate objective is to ensure the smooth functioning of society. Interpreting public convenience as such might also be logical since the FDRE Constitution looks up to international treaties like ICCPR for interpreting fundamental rights recognized by it. ${ }^{46}$

The other ground for limiting freedom of assembly in the Constitution i.e. 'protection of democratic rights', does not sound sensible considering the unusual classification of human rights enshrined in it as 'fundamental rights and freedoms' on the one hand and 'democratic rights' on the other hand, without providing the criteria for classifying them as such. Under the first group, rights like right to life, liberty, freedom of religion and the right to fair trial are included inter alia. ${ }^{47}$ The second category (i.e. democratic rights') includes freedom of speech, association, assembly, right of women, right to vote, right of children etc... ${ }^{48}$ A textual reading of the FDRE Constitution leads to the conclusion that, freedom of assembly is susceptible to limitation only where democratic rights listed above are threatened which does not make any sense. Hence, the broad stipulation of 'rights of others' envisaged in the ICCPR sounds more logical and inclusive.

However, the listing of legitimate grounds for restricting freedom of assembly by the Constitution is only the first step that prevents an arbitrary limitation of the right. A full-fledged protection requires suitability of the chosen means, necessity and proportionality. Yet, the FDRE Constitution does not go beyond qualifying limitations on freedom of assembly with a phrase 'appropriate regulations'. 49 No implementing legislation or decision of an Ethiopian court has elaborated what makes a regulation appropriate and the parameters for saying so. It is only through an extended constructive interpretation and reference to international human rights instruments ratified by Ethiopia that one may arguably contend that appropriateness refers to suitability, necessity and proportionality tests of acceptable limitation.

This author uses the word suitability in reference to the need to ensure that the means chosen by the legislature for regulating freedom of assembly must in one way or another contribute for attaining the legitimate aims. ${ }^{50}$ If the means has no connection with the objective intended to be achieved, it would be unacceptable. The necessity requirement envisages the need to examine the

\footnotetext{
${ }^{46}$ FDRE Constitution, supra note 6, art. 13(1).

${ }^{47}$ Id., art. 15, 17, 20\& 27.

${ }^{48}$ Id., art. 29-44.

${ }^{49}$ Id., art. 30 .

${ }^{50}$ Dieter Grimm (2007), "Proportionality in Canadian and German Constitutional Jurisprudence", University of Toronto Law Journal, Vol.7 (2007) p. 390.
} 
various alternatives available for addressing the concerns, based on which the legislature must select the one which entails the smallest impairment to persons exercising their right to freedom of assembly. ${ }^{51}$ Assuming that, the legislature meets the necessity requirement, the final step is determining proportionality by weighing the respective gain or loss for the rights concerned.

This requires putting two things on the scale: the social importance of the purpose served by the limitation of the right in question i.e. freedom of assembly vis-à-vis the damage the right sustains because of the restriction. ${ }^{52}$ If the balance between the two is right, then the government measure would be a sound limitation of the right. In contrast, if the cost to the right caused by the limitations significantly exceeds the social importance gained because of its limitation, then the government measure would be held unconstitutional because it fails to pass the key test of proportionality which is a criterion used in the balance.

\section{Notification Requirement of Assemblies}

The Peaceful Demonstration and Public Political Meetings, Proclamation predates Ethiopia's current Constitution. The Proclamation was initially designed to facilitate the exercise of political rights after their total demise during the Derg military regime. The preamble of the Proclamation provides that the objective of the law is to enable people 'start enjoying their democratic rights forthwith, until detailed laws are worked out and promulgated' ${ }^{53}$ Yet, the promise of the Proclamation is still unfulfilled (even long after the adoption of the Constitution), and there are several problems and controversies with regard to its contents and application.

Unlike most fundamental freedoms, the exercise of the right to freedom of assembly needs compliance with certain procedural requirements set by the legislature. ${ }^{54}$ This is almost a universal reality and it is difficult to find a jurisdiction which does not attach a procedural pre-condition for its realization. The main procedural requirement that organizers have to comply with in many systems is that of 'giving notice' to or 'seeking authorization' from the authorities. ${ }^{55}$ It is sometimes difficult to point out the real difference between 'notice' and 'permission', since the authorities regulating freedom of assembly could prohibit the undertaking of the assembly on the basis of facts stated in the notice. For instance, the African Commission on Human and Peoples Rights

\footnotetext{
${ }^{51}$ Id., p.389.

${ }^{52}$ Id., p. 340.

${ }^{53}$ Demonstration and Political Meeting Proclamation, supra note 7 Preamble.

${ }^{54}$ Salat, supra note 2, p.55.

${ }^{55}$ Id., pp. 58 \& 72.
} 
Working Group reports that despite the absence of a legal requirement of seeking permission for organizing an assembly in some systems, 'in practice the state often refuses to grant permits to assemblies critical of the government. ${ }^{, 56}$ Yet, the requirement of giving notice of 'intent' to conduct an assembly is regarded as sufficient and ideal measure, rather than imposing the duty of asking permission from the authorities to exercise the right. The prerequisite of permission will relegate the right to freedom of assembly to a privilege dependent on the goodwill of those regulating it. ${ }^{57}$ Further, it is imperative to note that the prime purpose of notification must be facilitating the smooth undertaking of an assembly by making necessary arrangements in advance. ${ }^{58}$

As a matter of theory, Ethiopia follows the notification system for controlling assemblies, by virtue of the Demonstration and Public Political Meeting Proclamation. ${ }^{59}$ The key provision in this regard is article 4 of the Proclamation which stipulates the procedure for submitting notice. Accordingly, it provides that 'any individual, group or organization that organizes a peaceful demonstration or public political meeting has the obligation to give written notice 48 hours before the intended peaceful demonstration or public political meeting is to take place'. ${ }^{60}$ The timeframe for submitting notification provided by the Ethiopian law is reasonable considering the time authorities, organizers and police need to properly facilitate the undertaking of the assembly. In other jurisdictions, the duration of notification for assemblies ranges from 6 hours to 28 days. ${ }^{61}$

The Proclamation requires the notice to be presented to the administration of the municipality (or to local administrations in rural areas). Here, it is important to note various points related with the procedures of notification. First, both indoor and outdoor assemblies are subjected to the requirement of notice in Ethiopia. This is not the case in jurisdictions like Germany which do not require notification for indoor assemblies, ${ }^{62}$ the justification being the non-occurrence of traffic and other inconveniences as a result of such gatherings. Second, Ethiopia's law demands notification regardless of the size of assembly or the number of participants. This deviates from the practice in many jurisdictions.

\footnotetext{
${ }^{56}$ African Commission on Human and Peoples Right (ACHPR), Report of the Study Group on Freedom of Association \& Assembly in Africa, (2014), p. 61.

57 'Factsheet: Recommendations on Managing Assemblies Joint Report of Special Rapporteurs Maina Kiai and Christof Heyns to the Human Rights Council', March 2016 (A/HRC/31/66).

${ }^{58}$ OSCE/ODHIR supra note 1, s.1 para.4.1.

${ }^{59}$ Demonstration and Political meeting Proclamation, supra note 7.

${ }^{60}$ Id., art. 4(1).

${ }^{61}$ Jarman and Hamilton, supra note 23.

${ }^{62}$ Basic Law of the Federal Republic of Germany 2010, art 8.
} 
For instance, the Armenian assembly law exempts small gatherings up to 100 participants from the requirement of notification. ${ }^{63}$

Likewise, the UN Special Rapporteur on Freedom of Assembly and experts of OSCE/ODIHR argue for the exemption of assemblies with insignificant number of participants from observing notification pre-condition. ${ }^{64}$ Their argument centers on the very purpose of notification which is 'facilitate' the undertaking of an assembly by addressing possible concerns such as traffic and security issues in advance. ${ }^{65}$ If the number of the assembled individuals is very few, it is unlikely for them to cause disruption to traffic or societal order. Hence, to require notice for such assemblies might defeat the underlying rationale of notification and it will be a disproportionate restriction of the right. Yet, what constitutes a small assembly is still controversial.

Aside from the features of notification highlighted in the preceding paragraphs, the Ethiopian law regulating assemblies also provides what a letter of notification should contain. Accordingly, notice submitted by organizers is required to state: the objective of the assembly, place of conducting it, routes it goes through, date, time, estimation of possible attendees and finally the kind of assistance they expect from the city administration in the course of undertaking the assembly. ${ }^{66}$ The law does not specify the purpose of requiring these details even if one can presume that it is to make the necessary arrangements in advance. On this issue, the UN Special Rapporteur underscores the need to go beyond presuming the government's duty of cooperation in facilitating assemblies. Rather, a clear statement of this duty in a legislation (that regulates assembly) is necessary for the effective protection of the right. ${ }^{67}$

Hence, the explicit obligation imposed on the security personnel by the Ethiopian assembly law to ensure peace and security ${ }^{68}$ might be considered as a step in the right direction, if it is implemented properly. Yet, the Ethiopian law is silent about the possibility of making modification to a notification of assembly that is submitted and the consequences that follow. On this matter, the stipulation of the Armenian assembly law can offer insights. If the organizers make changes that affect the essence or the notified assembly, Armenia's law

\footnotetext{
${ }^{63}$ Republic of Armenia Law on Freedom of Assemblies 2011, art. 9(1) \& 24.

64 'Report of the Special Rapporteur on the Right to Freedom of Peaceful Assembly and of Association' , Maina Kiai, A/HRC/20/27 (2012) par.28, \& OSCE/ODIHR, Venice Commission Guidelines on Freedom of Assembly, (2 ${ }^{\text {nd }}$ ed Venice, 2010) para. 115.

${ }^{65}$ Ibid.

${ }^{66}$ Demonstration and Political meeting Proclamation, supra note 7, art. 5(1).

${ }^{67}$ Report of the Special Rapporteur on the Right to Freedom of Peaceful Assembly and of Association , Maina Kiai, (hereinafter report of the Special Rapporteur ) A/HRC/20/27 (2012) para.27.

${ }^{68}$ Demonstration and Political meeting Proclamation, supra note 7, art 6(1).
} 
requires them to submit a new notice. ${ }^{69}$ We can infer that the change made is major or substantial. In contrast, if the change is very minor and insubstantial, the authorities must tolerate the deviation and facilitate the assembly without demanding the re-submission of notice.

Once the notification is received, the Ethiopian assembly law gives 12 hours for the authorities to make a decision on it. ${ }^{70}$ The inclusion of time limit for decision making is a positive thing since it helps to ensure timeliness of decision and accountability of authorities. The verdict of the administrative officials could either be to give the green light for the assembly to proceed as planned or to make a suggestion for the undertaking of 'the public demonstration or public political meeting to be held at some other time or place. ${ }^{71}$ The grounds for postponing the assembly to another venue or time must relate to concerns of safeguarding peace, security or preventing the disruption of the day to day activities of the public. ${ }^{72}$

These grounds seem to give authorities broader power and discretion for postponing assemblies compared to other jurisdictions like Kenya. Under Kenyan assembly law, the only ground that justifies the postponement or relocation of a planned assembly is the prior reservation of the place selected for the gathering by another assembly to be conducted at the same time. ${ }^{73}$ Thus, Kenya's law does not allow the undertaking of two assemblies having different objectives at the same place and time. This seems true for Ethiopia as well, even if the law is silent on that issue. However, such practice of banning counter demonstrations is regarded by the UN Special Rapporteur as unjustified restriction on freedom of assembly. ${ }^{74}$ The ideal solution is to find a means of conducting both assemblies without prejudicing each other.

\section{Gaps and Practical Challenges in the Notification Regime for Assemblies}

In the preceding paragraphs, an attempt has been made to provide a general outline of the Ethiopian notification regime through a comparative lens. The focus of this section is more on the gaps in the law and challenges of implementation as observed in different practical cases. The discretionary interpretation of the notification provision of the Ethiopian assembly law gives a

${ }^{69}$ Republic of Armenia Law on Freedom of Assemblies, supra note 63, art. 14(5).

${ }^{70}$ Demonstration and Political meeting Proclamation, supra note 7, art.6 (2).

${ }^{71}$ Ibid.

${ }^{72}$ Ibid.

${ }^{73}$ Public Order Act Chapter 56 of the Laws of Kenya. Rev. 2009, s. 5(12).

74 'Report of the Special Rapporteur on the Right to Freedom of Peaceful Assembly and of Association', Maina Kiai, A/HRC/20/27 (2012) para. 30. 
partial explanation for the absence of a single demonstration in the Ethiopian capital between $2005-2013 .{ }^{75}$ It is also cited as an explanation for the failure of the majority of assemblies subsequent to 2013. One could only find a handful of assemblies conducted successfully since then.

\subsection{Issues Related to Receipt of Notification, Decline and Silence}

The problem begins with the refusal on the part of the administrative officials to receive the letter of intent to conduct assembly by the organizers. This happens often when the place, time or purpose of the assembly is not agreeable to the authorities for various reasons. A good example of such a case could be the demonstration organized by Semayawi Party (Blue party) in Addis Ababa, on September 7, 2013. ${ }^{76}$ The press release of the party indicated that it approached the Addis Ababa City Administration Peaceful Demonstration and Meetings Notification Department on September 5, 2013 with a letter of notification to conduct a demonstration on the said date but the latter declined to receive the notification. The party also sent the same letter via Ethiopian Postal Service but, according to the statement made the party, the notification department of the municipality was still defiant to receive the letter. ${ }^{77}$ This was later resolved after leaders of the party discussed the matter with the Office of the Mayor and got the explanation that it is impossible to conduct the assembly on the planned date since various public places in the city will be occupied by sale exhibition of small micro enterprises operating in the city; this forced the party to postpone the demonstration for another time. ${ }^{78}$

Evidently, the refusal of the authorities to receive the letter of notification is an arbitrary exercise of their power. If they have a problem with the undertaking of the assembly on the planned date and time, what they should do is accept the notification and give whatever decision they think is appropriate by taking into account the principle of proportionality. This problem is partly due to the gap in the implementing legislation as it fails to clearly order authorities to accept any notification that meets the formality requirement set by the law. Further, there is no mechanism of verifying whether the authorities have received notification of an assembly. This is often a cause for evidentiary controversy between the organizers of an assembly and the authorities in Ethiopia. To address this

75 Solomon Goshu, 'Peaceful Political Rallies: The Right Besieged by Hurdles', The Reporter, 31 January $2015<\mathrm{http}$ //allafrica.com/stories/201502020437.html> accessed on 31 March 31, 2016.

76 'Blue Party Demonstration Postponed to 22 September 2013' (Amharic), $<$ http:/hornaffairs.com/am/2013/09/05/ethiopia-blue-party-statement-demonstration/> accessed 31 March 2016.

${ }^{77}$ Ibid.

${ }^{78}$ Ibid. 
problem, the experience of Kenya, Armenia and the recommendations of UN human rights bodies are relevant.

The Kenyan Public Order Act provides that 'the regulating officer shall keep a public register of all notices received. ${ }^{79}$ It also gives the public the right to examine or inspect the register of notifications in the opening hour of office. ${ }^{80}$ Likewise, the Armenian assembly law besides demanding recording of the notice in a special register, also requires the authorities to immediately post a copy of the submitted notice in the 'administrative building' of the authority as well as on its website. ${ }^{81}$ This practice is also regarded by the UN Special Rapporteur as a measure on the right track that ensures transparency and accountability. He further endorses the suggestion of the Venice Commission of Experts requiring the inclusion of a provision that forces authorities to immediately issue receipt of acceptance of notification. ${ }^{82}$ Incorporation of such a provision in the Ethiopian legal regime that regulates assemblies would have helped in resolving some of the issues.

Another problem relates to the failure on the part of the Ethiopian authorities to communicate (to the organizers) their decision on the status of received notification within the prescribed period set by the law. In some cases, the organizers considered the silence of the municipality administration office as acceptance or recognition and have suffered from the consequences such as imprisonment and violent dispersal of the assembly. An example to this problem is the demonstration that was organized (for March 17, 2013) by the Blue party, Baleraey Wetatoch Mahiber (Visionary Youth Association) and Private Initiative Committee for the Defense of Ethiopian People's Dignity and Heritage. ${ }^{83}$ The notice dated March 4, 2013 was addressed to the Addis Ababa City Administration Peaceful Demonstration and Meeting Notification Department. It states that the purpose of the demonstration is to oppose the construction of a museum and memorial park in Italy for Rodolfo Graziani who is regarded as a fascist war criminal by the organizers as he massacred thousands of Ethiopians during the 5 years of Italian occupation. ${ }^{84}$

The form of the assembly planned was a procession that starts at Yekatit 12 square where the statute of martyrs massacred by Graziani is located, and the

\footnotetext{
${ }^{79}$ Public Order Act, supra note 73, s 5(14).

${ }^{80}$ Ibid.

${ }^{81}$ Republic of Armenia Law on Freedom of Assemblies, supra note 63, art. 15.

${ }^{82}$ OSCE/ODIHR, 'Joint Opinion on the Draft Law on Peaceful Assemblies of the Kyrgyz Republic by the Venice Commission and OSCE/ODIHR', Opinion no. 525/2009 (22 June 2009) s37.

${ }^{83}$ Ethiopia arrests 43 anti-Graziani statue protesters in Addis Ababa' $<$ http://www.awrambatimes.com/?p=13407> accessed 31 March 2016

${ }^{84}$ Ibid.
} 
final destination was planned to be the Embassy of Italy in Addis Ababa. According to the organizers, the Municipality accepted the notification and kept silent. They took its silence as a tacit approval and went on to conduct the demonstration as planned. However, the Police dispersed the assembly as illegal for failing to get recognition from the Administration and it arrested 43 individuals who participated in the demonstration. ${ }^{85}$ Such problems could have easily been resolved had the Ethiopian assembly law clearly provided the consequences of inability or unwillingness of the administrative officials to render and communicate their decisions within the timeframe set by the law like the one provided in the Armenian assembly law. In this regard, the Armenian law on assemblies states that failure to make a timely decision on notifications is 'considered as that the notification is acknowledged' ${ }^{86}$ Similarly, the UN Special Rapporteur and Venice Committee of Experts note that the principle that silence amounts to acceptance shall govern such situations and the law should allow demonstrators 'to proceed with the planned assembly in accordance with the terms notified and without restriction. ${ }^{87}$

\subsection{Treatment of Spontaneous Assemblies in Ethiopia}

The other problematic issue in the Ethiopian legal regime governing notification of gatherings is that of 'spontaneous assemblies'. According to the Venice Committee of Experts, such assemblies refer to those 'organized in response to some occurrence, incident, other assembly, or speech, where the organizer (if there is one) is unable to meet the legal deadline for prior notification, or where there is no organizer at all. ${ }^{, 8}$ As their name suggests, these assemblies are accidental and not planned in advance. What usually induces their occurrence is a certain unforeseen event which is of interest to the public. Such incidents might induce the public to react immediately by going out to the streets without observing the notification requirement for normal assemblies. Various authorities including the UN Special Rapporteur on freedom of assembly recognize such kind of assemblies as exceptional in nature deserving a special treatment. ${ }^{89}$ Thus, states are expected to devise (in their laws) a mechanism of allowing such assemblies without requiring the ordinary process of notifying assemblies which might take some time. Further, demanding spontaneous assemblies to go through similar notification procedure deprives their immediate nature and undermines their value..$^{90}$

\footnotetext{
${ }^{85}$ Ibid.

${ }^{86}$ Republic of Armenia Law on Freedom of Assemblies, supra note 65, art.20(3).

${ }^{87}$ Interim Joint Opinion on the Draft Law on Assemblies of the Republic of Armenia by the Venice Commission and OSCE/ODIHR, Opinion no. 596/2010 (22 December 2010) s.40

${ }^{88}$ OSCE/ODHIR , supra note 1, para. 126.

${ }^{89}$ Report of the Special Rapporteur, supra note 67, para. 29.

${ }^{90}$ Ibid.
} 
Ethiopia's law (indicated in footnote 7 above) that regulates freedom of assembly does not leave a room for making any exception for spontaneous assemblies regarding notification requirement. The law treats spontaneous assemblies as any other form of assembly and does not provide a special treatment. This lacuna in the law has created a serious problem for exercising the right to freedom of assembly in Ethiopia as it deprives spontaneous assemblies from any protection.

Two cases of spontaneous assemblies which were dispersed by security personnel -for failing to give advance notice- illustrate this problem. The first spontaneous demonstration took place in Addis Ababa on November 15, 2013 in front of the Saudi Arabia Embassy. What triggered the demonstration was the killing of three Ethiopians by the Saudi police and the decision of the Saudi government to deport around 23,000 illegal workers of Ethiopian origin. ${ }^{91}$ The release of a video showing 'a crowed dragging an Ethiopian from his house and beating him' created grievance in the public. Banners carried during the demonstration show the disappointment of the people on the Ethiopian government's careless handing of the problem and its failure to safeguard the interest of Ethiopian citizens working abroad. ${ }^{92}$ The reaction of the police was to disperse the demonstrators and arrest some of the participants on the allegation that they conducted a demonstration without getting the approval of the city administration. In his response to the AFP broadcasting agency, the then spokesperson of the government Shimeles Kemal noted that the demonstration was terminated because 'it was an illegal demonstration, they had not [obtained] a permit from the appropriate office' ${ }^{93}$

The second example of spontaneous assembly is the one that was dispersed by the Police. It was triggered by a video released by the ISIS which showed the beheading of 28 Ethiopian Christians in Libya. ${ }^{94}$ In his statement, the then government spokesperson Redwan Hussein said that 'it was not clear if the victims were Ethiopians and the Ethiopian Embassy in Cairo was investigating

91 'Police crackdown on demonstrations against targeted attacks on Ethiopian migrant workers in Saudi Arabia' <http://www.aljazeera.com/news/africa/2013/11/arrests-at-antisaudi-protest-ethiopia-201311151464025832.html> accessed: 31 March 2016.

92 'Ethiopian Police Crackdown on Anti-Saudi Protest'.

$<$ http://bigstory.ap.org/article/ethiopian-police-crackdown-anti-saudi-protest $>$ accessed on 31 March 2016.

93 'Police Crackdown on Demonstrations against Targeted Attacks on Ethiopian Migrant Workers in Saudi Arabia' <http://www.aljazeera.com/news/africa/2013/11/arrests-at-antisaudi-protest-ethiopia-201311151464025832.html> accessed 31March 2016.

94 'Police Forcefully Disperse Protests Held by Ethiopians Against ISIS Killings' $<$ http://addisstandard.com/police-forcefully-disperse-protests-held-by-ethiopians-againstisis-killings/> accessed 31 March 2016. 
the matter', and this statement further added fuel to the fire. ${ }^{95}$ Aggrieved with the reaction of the government on the incident, thousands went out to the streets on April 21, 2015 (without any organizer) by carrying banners with statements saying 'where is our government', 'justice for the dead', 'sovereignty is the safety of citizens everywhere in the world' and 'don't tell us they are not ours'. ${ }^{96}$

The city administration reacted by deploying members of Addis Ababa police and federal police forces, and stopped the protestors from heading to the headquarters of the African Union and National Palace. ${ }^{97}$ Like the Saudi protest discussed above, no violence on the part of the protesters was reported. Such practice of dispersing spontaneous assemblies by administrative officials and police forces stands in direct contrast with the position of the UN Human Rights Committee. ${ }^{98}$ This prompts another crucial issue regarding the fate of assemblies conducted without giving notice.

\subsection{Fate of Assemblies without Notice}

Ethiopian assembly does not clearly provide the measures taken against gatherings that are conducted without prior notification. The practice in Ethiopia shows that, any public demonstration or public political meeting which fails to comply with the requirement of notification is by definition illegal and forbidden. It usually ends up with dispersal and with filing of criminal charges against participants of such assembly. ${ }^{99}$ The Criminal Code of Ethiopia also contains a provision that penalizes persons who take part in an assembly prohibited by law which includes gatherings undertaken in the absence of notification. ${ }^{100}$ It also extends criminal liability to those who avail their land, property or hall to such assemblies. ${ }^{101}$

On the contrary, the UN Human Rights Committee has (in several cases before it) decided that mere failure of organizers to notify authorities does not give the latter an automatic power to disperse the assembly and arrest participants so long as the assembly is peaceful. For example, the case of Igor Bazarov v Belarus ${ }^{102}$ involves the dispersal of a street procession conducted by the applicant and his subsequent liability for administrative offences. Igor, a citizen of Belarus, conducted a street procession on March 25, 2009 with two

\footnotetext{
95 Ibid.

96 Ibid.

${ }^{97}$ Ibid.

${ }^{98}$ Igor Bazarov v Belarus, Human Rights Committee(Communication No. 1934/2010 ) 29 august 2014.

99 'Ethiopia arrests 43 anti-Graziani statue protesters in Addis

Ababa'<http://www.awrambatimes.com/?p=13407> accessed 31 march 2016

${ }^{100}$ The Criminal Code of Ethiopia 2004, art 482(1) a.

${ }^{101}$ Id., art 482(1) b.

${ }^{102}$ Igor Bazarov v Belarus, supra note 98.
} 
other participants without getting permission from the appropriate organ of the city. Their march began at independence square and they were waving a 'white, red, white' flag which they think is 'symbol of revival for Belarus." 103 After conducting the procession for 10 minutes, police stopped their march and took custody of Igor on the ground that he conducted the procession without getting authorization which is required by law. He was later found guilty of committing an administrative offence of undertaking a procession lacking permission and was fined 70, 000 Belarusian Rubles. ${ }^{104}$ Aggrieved with the decision of Belarusian courts, the applicant approached the UN Human Rights Committee alleging the infringement of the right to freedom of assembly recognized by the ICCPR and Belarusian Constitution.

In its decision of 2014, the Committee found that Belarusian authorities have violated the right to freedom of assembly. The reasoning of the Committee underlined that the right to freedom of assembly is enshrined in the Constitution of Belarus and the state is also a party to the ICCPR which recognizes the right under article 21. The Committee noted that in restricting the right to freedom of assembly, Belarus must comply with the safeguards of necessity and proportionality incorporated in the Covenant. It particularly rejected the contention of Belarus that the measure has a legal backing since the law requires permission before conducting any procession.

The argument of the Committee was that Belarus 'has not attempted to explain why it was necessary -under domestic law and for one of the legitimate purposes set out in ... the second sentence of article 21 of the Covenant- to obtain authorization prior to holding a peaceful street march in which only three persons intended to participate. ${ }^{105}$ For such restriction to be justified, the Committee found that the state must go beyond citing a law that demands authorization by showing how 'the movement of the author and his two acquaintances' holding a flag along the pavement down a pedestrian street during daytime would have violated the rights and freedoms of others or would have posed a practical 'threat to public safety or public order (ordre public)' ${ }^{106}$ This decision shows that the Committee demands states to strictly observe the requirement of proportionality whenever they restrict the right to freedom of assembly by law or its application. Hence, they must discharge their burden of establishing a link between the legitimate aims and the restrictions as well as the non-availability of other less prejudicial means for the right that s state seeks to limit.

\footnotetext{
${ }^{103}$ Id., para.2.8.

${ }^{104}$ Id., para 2.1 .

${ }^{105}$ Id., para.7.5.

106 Ibid.
} 
A similar pronouncement was made by the Committee in the case, Sergey Kovalenko v Belarus. ${ }^{107}$ On October 30, 2007 the applicant was joined by thirty other people who also lost their families during the Stalin era which they characterized as repressive. Their plan was to move around the various places in the town of Vitebesk where their relatives were killed or buried and pay tribute to them particularly 'to lay wreaths and flowers and to erect a cross. ${ }^{108}$ By these gestures, they also wanted to show their disapproval of any form of political suppression or the silencing of dissent. ${ }^{109}$ This event was organized without seeking authorization from the city administration. Accordingly, after they finished their first commemoration in one of the places and boarding a bus to move to other places, the police arrested every participant on the allegation that they took part in a picket or stationary assembly which is not permitted by city officials. Subsequently, the organizer of the event Sergey was ordered by court to pay 620,000 Belarusian Rubles for his violation of the administrative law that requires seeking permission from authorities before conducting any form of assembly. ${ }^{110}$ Being upset with the finding of the court, the applicant submitted a case to the UN Human Rights Committee claiming violation of the right to freedom of assembly enshrined in the ICCPR.

After a careful consideration of arguments of both parties, the Committee held in favour of the applicant and found Belarus responsible, inter alia, for violation of the right to freedom of assembly. ${ }^{111}$ The Committee reiterated its reasoning in the Igor Bazarov case (discussed above) by indicating that no evidence is adduced by the state which shows how the commemoration event actually endangers 'national security or public safety, public order (ordre public), the protection of public health or morals or the protection of the rights and freedoms of others' ${ }^{112}$ The two decisions of the Committee (in the Igor Bazarov and Sergey Kovalenko cases) conform to the position held by the UN Special Rapporteur on the right to freedom of assembly as well as by the Venice Commission of Experts. The decisions in both cases require states to refrain from dispersing spontaneous assemblies or gatherings with negligible number of participants by merely invoking failure to comply with a notification requirement as it violates the principle of proportionality. ${ }^{113}$ A similar ruling

${ }^{107}$ Sergey Kovalenko v Belarus, Human Rights Committee (Communication No. 1808/2008) 26 September 2013.

${ }^{108} \mathrm{Id}$, para.2.1.

${ }^{109}$ Ibid.

${ }^{110}$ Id., para. 2.1

${ }^{111}$ Id., para.8.7.

112 Ibid.

113 'Report of the Special Rapporteur on the Right to Freedom of Peaceful Assembly and of Association' , Maina Kiai, A/HRC/20/27 (2012) par.28, \& OSCE/ODIHR , Venice Commission Guidelines on Freedom of Assembly, (2ed Venice, 2010) para. 115. 
was given by the African Commission in Malawi African Association and Others v. Mauritania. ${ }^{114}$

The above decisions of the Committee have serious implications for Ethiopia as a state party to the ICCPR. This is because, the country has a bad reputation of dispersing gatherings conducted without compliance with the notification procedure and subjecting participants to criminal liability as noted in several parts of this article. The recent protest of a few Addis Ababa University students in front of the US Embassy ${ }^{15}$ shows the level of intolerance of Ethiopian authorities towards assemblies conducted without notice irrespective of whether they pose security risk or not. This protest was held on March 8, 2016 by disregarding the notification requirement set by the Demonstration and Public Political Meeting Proclamation and the number of participants was 20 (twenty). As the video footage of the demonstration shows, the students were expressing their disapproval of the government's handling of the recent crisis in Oromia regional state in entirely peaceful manner. ${ }^{116}$ They were even carrying a white flag to demonstrate their peaceful intention. Since their number was few, they did not block the road nor prevent the free flow of cars and people. Yet, the authorities immediately arrested the students and criminal charges were pressed against them.

The first count accused the students of violating Article 486(1) (a) of the FDRE Criminal Code which forbids assemblies conducted in violation of the law. Here, the contention of the prosecutor is that the students violated this article by failing to notify the city administration and for carrying out a demonstration in front of an Embassy in violation of the Demonstration and Public Political Meeting Proclamation. ${ }^{117}$

In the second count, the prosecutor alleged that the students are responsible for spreading false rumours against the government and inciting the public by carrying placards ${ }^{118}$ such as "Schools are Knowledge Camps, not Military Camps", "Stop the Genocide Against the Oromo People", "The Government should take Responsibility for those Killed", "Stop the Killings and Evictions", "The Government should Withdraw its Military from Oromia Region", "The Ethiopian Defense Force is terrorizing the Oromo People", "Stop giving Lands to Investors while Citizens are Starved", "The Government of America Should

\footnotetext{
${ }^{114}$ Malawi African Association and others v Mauritania, Comm. Nos 54/91, 61/91, 98/93, 164-196/97 \& 210/98 (2000), paras 108-11.

${ }^{115}$ Public Prosecutor v Sorresa Demme et al, Federal First Instance Court Menagesha Bench Reference no. GJBPPFNO 01716/08, 16 march 2016 (criminal charge).

116 Ibid.

${ }^{117}$ Ibid.

118 Ibid.
} 
be aware of Ethiopia's Pseudo Democracy"119 in violation of Article 486(1) (a) of the FDRE Criminal Code. The third charge incriminated the students of infringing article 487(b) of the FDRE Criminal Code which prohibits inciting 'others to disobey orders issued by a lawful authority or to disobey laws or regulations duly promulgated'. ${ }^{120}$ The allegation of the prosecutor here is that with the intent of disobeying the law, students carried a placard which says "the Government of Ethiopia Should Amend the Anti Terrorism Law" and "Dissent is not Terrorism" $" 121$.

The criminal proceeding against the students is undergoing during the writing up of this article. Yet, few remarks could be made on the rationality of the charges brought against them in light of their right to freedom of assembly and other related constitutional rights. From the perspective of the right to freedom of assembly recognized by the Constitution, none of the allegations made by the prosecution would hold water. With regard to the first charge of demonstrations without giving notice in a prohibited place, the issue that arises is whether the restriction provided by the Public Demonstration Proclamation is appropriate. Specifically, the issue would be whether the law is reasonable in requiring notification for assemblies of a few participants (i.e., 20 in the case at hand) where such events do not pose danger to public peace, order or free flow of traffic. The purpose of notification is to facilitate assemblies, and such requirement would be cumbersome to uphold considering their right to freedom of assembly. Blanket ban on demonstrations before embassies without further qualification is unduly burdensome to demonstrators especially where their messages target at the officials in the premises of the Embassy.

Regarding the second accusation against them which is inciting the public and spreading false rumours against the government, it also does not make much sense. Content based limitation on participants exercising their right to freedom of assembly is only allowed if it is proved that they have made an unequivocal call for war or hatred. ${ }^{122}$ Apart from such cases, the right of demonstrators to criticize the actions or policies of the government is fully protected by their right to freedom of assembly and freedom of expression. The prime objective of these rights is to protect such views from unnecessary attack as long as they are expressed in a democratic and peaceful manner which seems to be the case. None of the messages included in the placards they carried even remotely call for violence or hatred. The sole claim of the prosecutor's charge is that what they are stating is false. For instance, the placard that regards Ethiopia's pledges

\footnotetext{
${ }^{119}$ Ibid.

${ }^{120}$ Federal Democratic Republic of Ethiopia, Criminal Code 2004.

${ }^{121}$ Public Prosecutor v Sorresa Demme, supra note 115.

122 OSCE/ODHIR , supra note 1, para. 94.
} 
to democracy as "Pseudo Democracy" is the expression of what the demonstrators genuinely believe to be the case based on their observations.

The government may believe that it is exercising a genuine democracy and it might consider the statements of the students as false. But is it fair to criminalize expression on a contestable issue such as the prevalence of democracy in Ethiopia solely because the statement is considered as false from the government's point of view? Is it not too cumbersome to demand citizens to keep quiet unless they are hundred percent sure that what they are saying is true from the government's standpoint? Would this ever be possible in constitutional democracy that upholds fundamental rights? I argue that this should not be the case because citizens must be allowed to say what they genuinely believe in without being required to prove its absolute veracity. A government may not agree with what every citizen says, but it should not criminalize citizens for saying so. Otherwise, recognizing freedom of assembly and expression become superfluous.

The third count of the prosecution accuses the students of inciting nonobservance of the anti-terrorism law by openly calling the government for its amendment. $^{123}$ One does not see the link between how the request for amendment of the law could be equated with a call for its disobedience. A number of important questions might ensue. Is it fair to criminalize citizens just for demanding an amendment of a law on anti-terrorism? What is wrong with even asking for the amendment of the Constitution or its replacement with another one so long as it is done in a democratic and peaceful manner? Overall, the outright criminalization of assemblies conducted in the absence of notification without risk of public order or peace in Ethiopia is inconsistent with the interpretation of the UN Human Rights Committee regarding freedom of assembly as envisaged in the ICCPR. Accordingly, it is time for Ethiopia to revisit its laws and practices on freedom of assembly and ensure their conformity with the country's obligations under international human rights treaties such as the ICCPR.

\section{5. 'Place, Time and Manner Restrictions' on Assemblies}

The other cluster of limitations that adversely affects the exercise of the right to freedom of assembly is the one connected with place, time and manner. Two forms of restrictions are envisaged in the Proclamation concerning the venue of conducting assembly. The first is an outright or blanket restriction on undertaking demonstrations or political meetings within 100 meters from the places identified as prohibited. ${ }^{124}$ A long list of such venues is provided in the

\footnotetext{
123 Ibid.

${ }^{124}$ Demonstration and Political meeting Proclamation, supra note 7, art 7(1).
} 
Proclamation which includes embassies, international organizations, hospitals, graveyards, churches, mosques, prayer houses, electric power houses, dams and 'unsuitable' market places on market days inter alia. ${ }^{125}$ Such blanket venue restrictions are regarded improper by the UN Special Rapporeur on the right to freedom of assembly. ${ }^{126}$ Further, no assembly could be conducted within 500 meter radius of detention centers, offices belonging to the military, or security personnel. ${ }^{127}$ These place restrictions are very broad and one may need to go to the wilderness to conduct an assembly if these restrictions are to be applied strictly without any proportionality considerations.

The Proclamation also gives a wide range of power to municipalities to seek postponement of time or relocation of place by citing concerns of peace, security and ensuring the continuation of people's 'daily life' without any 'disruption'. ${ }^{128}$ The manner in which the restriction is crafted is susceptible to wide interpretations especially in the Amharic version of the Proclamation. It states that the municipalities may recommend that it is preferable to undertake the assembly another time or place by stating their justifications. ${ }^{129}$ Here, it is important to bear in mind the distinction between a decision and a recommendation, the latter being non-binding. According to this interpretation organizers could disregard the suggestion of the administration as it lacks binding force.

On the other hand, the provision which allows a recommendation in the beginning, states decision in the end, by stating that the municipalities cannot do ban the conducting of an assembly at any time or place. ${ }^{130} \mathrm{~A}$ logical interpretation of the second part of the provision leads to the conclusion that, the city administration is at liberty to decide on postponement of time or changing of venue as often as it wants save for total prohibition of an assembly. The second line of interpretation seems to be the one agreeable to the municipalities of Ethiopia. Because, what they frequently do is ask organizers to relocate place or postpone date of the assembly upon receipt of notification by raising several concerns. ${ }^{131}$ If the decision is not accepted by the organizers they will refuse to endorse submitted notification which makes the planned assembly illegal. The following examples demonstrate this problem.

\footnotetext{
125 Ibid.

${ }^{126}$ Report of the Special Rapporteur, supra note 67, para. 39.

${ }^{127}$ Demonstration and Political meeting Proclamation, supra note 7, art. 7(2).

${ }^{128}$ Id., art. 6(1).

${ }^{129}$ Ibid. (Amharic version of the law).

${ }^{130}$ Ibid.

${ }^{131}$ Daniel Berhane, 'Semayawi's Foiled Rally: A Reminder of Ethiopia's Deeper Problems', $<$ http://hornaffairs.com/en/2014/12/16/ethiopia-blue-party-democratic-deficit/> accessed on April 1, 2016.
} 
An open sky demonstration was organized by Semayawi Party (The Blue Party) together with other opposition parties on November 25, 2014. ${ }^{132}$ The organizers submitted their notification to Addis Ababa City Administration. However, it declined to allow the assembly by alleging 'security force shortage as there are other scheduled events. ${ }^{133}$ It further advised the organizers to conduct an indoor assembly as an alternative. The organizers were not convinced with the justifications provided by the authorities after the expiry of the 12 hour period set by the law and proceeded with the assembly as planned. Then, the city administration quickly broke the gathering by deploying police force immediately. It also characterized the event as an 'anti-constitutional activity'. ${ }^{134}$

The coalition of parties submitted another notification to conduct a 24 hour demonstration at Meskel Square set to begin on December 8, 2014 and to finish on December 9, 2014 mid day. ${ }^{135}$ What makes this demonstration interesting was the day selected for its undertaking, i.e. December 8 which coincides with Nations and Nationalities day celebrated nationally. Some contend that the organizers chose this date on purpose to irritate the current government that celebrates this day, yet others say it is accidental. ${ }^{136}$ Leaving this aside, the city administration rejected to approve the notification as it did in the past. Its justification this time was 'the increased traffic [in the square] due to ongoing construction activities. ${ }^{137}$ This was followed by a statement by the government on national TV that warned the organizers to refrain from conducting the assembly as planned. Nonetheless, the coalition of parties defied the decision of the city administration and proceeded with the gathering until the police detained more than 75 participants including the leaders of different opposition parties. ${ }^{138}$ They were later accused of 'outrage against the Constitution' 'rioting' and 'inciting terror and chaos." 139

Moreover, the recent controversy between the Ethiopian Federal Democratic Unity Forum (MEDREK) which is a consortium of several opposition parties and the Addis Ababa City Administration further illustrate the magnitude of the problem. What caused the dispute was the refusal of the city administration to approve a notification submitted by the party for conducting demonstration on

\footnotetext{
132 Ibid.

133 Ibid.

${ }^{134}$ Ibid.

135 Ibid.

${ }^{136}$ Ibid.

${ }^{137}$ Ibid.

138 Ibid.

139 Ibid.
} 
three separate occasions. ${ }^{140}$ The party first notified the authorities of its intent to organize a peaceful procession on Sunday December 27, 2015. It also indicated the route that starts at a place called Afencho Ber passing through Ras Mekonnen Bridge, Churchill road and ending at tiglachen statute or Ethio-Cuba Friendship Park. The purpose of the march was to condemn the killing of protestors in the Oromia regional state and pay tribute for the dead. ${ }^{141}$ As noted time and again, the city administration refused to acknowledge the undertaking of the procession. Its justification for cancelling the procession was the presence of several higher learning and government institutions in the route chosen for the march, traffic congestion and the current situation of the country. ${ }^{142}$ These grounds were not convincing for the leaders of the party and they characterized them as "irrelevant and petty. ${ }^{, 143}$ Nonetheless, the administration stated that it will give approval to a demonstration that will be organized in another place 'with no traffic congestion. ${ }^{144}$

Accordingly, MEDREK presented another letter of notification to the city administration to conduct a procession on January 17, 2016. This time they chose another place as per the instruction of the administration but the objective of the march was the same as the one rejected earlier. The planned procession was set to start from Ginfile River and end at a place usually called Sholla Yeka Epiphany celebration place. ${ }^{145}$ Yet again, the city administration rejected the undertaking of the procession as the time and place chosen by the organizer is not agreeable to it because of the upcoming Epiphany holiday will be celebrated at the place chosen for demonstration. It further said that several international meetings including that of the African Union would be held in the same time and the timing of the procession is not acceptable. ${ }^{146}$ After hearing the response of the administration, the organizers noted that such decisions could only be

\footnotetext{
${ }^{140}$ Neamin Ashenafi, 'Cancellation of Planned Demonstration annoys Medrek'

$<\mathrm{http}: / / \mathrm{www}$.thereporterethiopia.com/content/cancellation-planned-demonstration-annoysmedrek> accessed 1 April 2016

${ }^{141}$ Ibid.

142 'Addis Ababa City Administration Turns Down MEDREK's Request for Demonstration Permit' <http://addisababaonline.com/addis-ababa-city-administration-turns-downmedreks-request-for-

demonstrationpermit/?utm_source=twitterfeed\&utm_medium $=$ twitter\&utm_campaign $=$ @aababaonline> accessed 1 April 2016

${ }^{143}$ Neamin Ashenafi, supra note 140.

144 'Addis Ababa City Administration Turns Down MEDREK's Request for Demonstration Permit' < http://addisababaonline.com/addis-ababa-city-administration-turns-downmedreks-request-fordemonstrationpermit/?utm_source $=$ twitterfeed\&utm_medium $=$ twitter\&utm_campaign $=$ @aababaonline> accessed on 1 April 2016.

${ }^{145}$ VoA Radio Amharic News 19 February 2016.

${ }^{146}$ Neamin Ashenafi, supra note 140.
} 
interpreted as absence of good faith on the part of the authorities and their unwillingness to allow the exercise of the constitutional right to freedom of assembly.

They particularly underscored the fact that the day chosen for procession in both cases was Sunday where there is no traffic congestion and the public institutions and schools are closed on that day. ${ }^{147}$ Concerning the Epiphany holiday, they said it was going to be celebrated three days after the planned demonstration and it is difficult to imagine how it could be a sufficient reason for banning the procession. The same is true for the said African Union meeting as it was due to be held fifteen days after the planned date of procession. ${ }^{148}$

Despite successive rejections, MEDREK submitted another notification to conduct a peaceful gathering at Meskel square on Sunday February 14, 2016. According to the organizers, the administration kept quiet this time but they received a threat from the police informally which made them to cancel the gathering. They further noted their frustration with the decision of the administration saying MEDREK's existence as a political party would be meaningless without freedom of assembly. The leaders of the party particularly said: 'if we are prevented from all this, then what instrument is left for us to remain politically active and visible as a political organization? ${ }^{149}$

The problems discussed in the preceding paragraphs raise several issues, the first being whether the authorities should have unlimited power to postpone time or change the venue for a planned assembly. To address this issue, it is important to bear in mind that one component of the right to freedom of assembly is the entitlement of organizers to choose the place and time they think is appropriate for achieving their purpose unless there is an overriding concern. A corollary of such entitlement is that authorities cannot arbitrarily make time and place restrictions as they wish by mentioning insignificant concerns.

On this issue, the UN Special Rapporteur and Venice Commission of Experts underscore that time and place restriction should take into account the principle of proportionality which requires legitimate aim, suitability, necessity and weighing the cost as well as the benefits of restriction. ${ }^{150}$ As such, a decision to postpone the assembly to another time or place must be made after due consideration of several factors, i.e. only when it is not possible to address the concern by using another measure which is less restrictive. Further, they noted

\footnotetext{
${ }^{147}$ Ibid.

148 Ibid.

${ }^{149}$ Ibid.

150 'Report of the Special Rapporteur on the Right to Freedom of Peaceful Assembly and of Association' , Maina Kiai, A/HRC/20/27 (2012) par.40, \& OSCE/ODIHR, Venice

Commission Guidelines on Freedom of Assembly, (2ed Venice, 2010) para.101
} 
that organizers are not obliged to comply with the suggestion of the authorities regarding alternative place and time for conducting the assembly if it undermines the 'essence' of the gathering. ${ }^{151}$

A good example in this regard could be the suggestion of the Addis Ababa City Administration to Semayawi Party to conduct an indoor meeting in a hall instead of undertaking a demonstration in Meskel Square. Such alternatives obviously erode the essence of the gathering since the purpose and effect of an open sky demonstration and a meeting in a closed hall cannot be identical. This is because freedom of assembly includes a right of undertaking a demonstration within 'sight and sound' of its target audience. ${ }^{152}$ Hence, whenever the administration seeks to apply time and place restriction -including postponement or relocation- it must go through every step in the scrutiny of proportionality to ensure the legitimacy of the measure.

The same position is reflected in the jurisprudence of the UN Human Rights Committee. In Denis Turchenyak $v$ Belarus, ${ }^{153}$ the applicants sought the permission of Brest City Administration for conducting a picket of 10 people for three days from $1 \mathrm{pm}$ to $3 \mathrm{pm}$ in an area reserved for pedestrians. The city administration rejected their application by citing a bylaw which designates 'Lokomotive Stadium' as the only place of undertaking a picket. ${ }^{154}$ Courts also affirmed the decision of the authorities as appropriate. This forced the applicants to approach the UN Human Rights Committee alleging the violation of their right to freedom of assembly.

Their main contention was, the alternative place available for them is an 'isolated location in a stadium that is surrounded by a concrete wall' which detaches them from their target audience making their whole activity futile. ${ }^{155}$ The Committee endorsed their argument by reasoning that the place restriction of the authorities on the applicants is capricious and disproportionate since it was imposed without showing 'how a picket held in the said location would necessarily jeopardize national security, public safety, public order, the protection of public health or morals or the protection of the rights and freedoms of others.' ${ }^{156}$

This would take us to another related question whether there should be a hierarchy among different uses of public spaces like streets, parks or squares. The other question is whether the utilization of public places for conducting

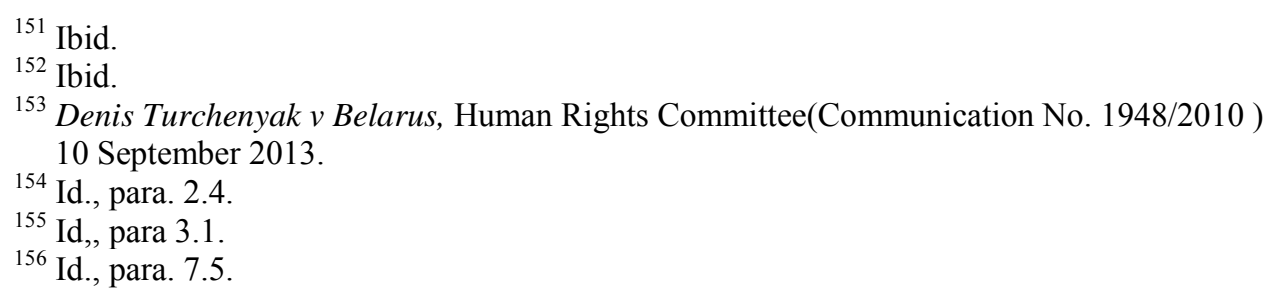


gatherings is of secondary importance compared to other uses such as traffic, trade fairs or celebration of religious festivals. Addressing these issues is very crucial since the practice in Ethiopia seems to favour the use of public places for other purposes than for conducting demonstration and public political meetings. As noted in different parts of this article, the Addis Ababa City Administration has repeatedly cancelled various notifications for conducting demonstrations by raising concerns for the smooth flow of traffic or the occupation of these places by other activities such as trade exhibition of micro-enterprises and giving an outright priority for the latter. ${ }^{157}$

Such practice is contrary to the recommendation of the UN Special Rapporteur on the right to freedom of assembly and Venice Commission of Experts. Both authorities underscore the need to give equal value for the utilization of public spaces for assemblies by stating that 'the free flow of traffic should not automatically take precedence over freedom of peaceful assembly. ${ }^{158}$ The Venice Commission of Experts further notes that 'assemblies are as much a legitimate use of public space as commercial activity and the movement of vehicular and pedestrian traffic. ${ }^{159}$ As such, administrative officials must not consider assemblies as having a secondary importance which could be easily forfeited whenever a competing use arises. Such approach violates the proportionality that must be observed whenever freedom of assembly is restricted. Hence, the municipality is duty bound to come up with a mechanism to reconcile various uses instead of invariably choosing to sacrifice the undertaking of assemblies for the sake of other uses. For instance, concerns of traffic flow could easily be addressed by 'rerouting pedestrian and vehicular traffic in a certain area. ${ }^{160}$

It is also important to bear in mind that, any restriction imposed on freedom of assembly should be in line with ideals of democracy as enshrined in the FDRE Constitution and ICCPR. ${ }^{161}$ The hallmark of a democratic society is its tolerance of minor inconveniences and its ability to accommodate various legitimate interests without imposing unnecessary burden on some for the sake of others. Authorities regulating freedom of assembly need to appreciate that 'in

\footnotetext{
157 'Blue Party Demonstration Postponed to 22 September 2013' (Amharic),

$<$ http:/hornaffairs.com/am/2013/09/05/ethiopia-blue-party-statement-demonstration/> accessed on March 31, 2016.

158 'Report of the Special Rapporteur on the Right to Freedom of Peaceful Assembly and of Association' , Maina Kiai, A/HRC/20/27 (2012) par.41, \& OSCE/ODIHR, Venice Commission Guidelines on Freedom of Assembly, $\left(2^{\text {nd }}\right.$ ed Venice, 2010) para.3.2 \& 20.

${ }^{159}$ Ibid.

160 Ibid.

${ }^{161}$ Constitution of Kenya, 2010, art. 37; International Covenant on Civil and Political Rights (adopted 16 December 1966, entered into force 23 March 1976) art. 21
} 
a democratic society, the urban space is not only an area for circulation, but also for participation. ${ }^{162}$ This shows that the provision of the Ethiopian assembly law that gives municipalities the power to restrict assemblies as they wish on account of preventing 'disruption of ordinary life of the people'163 must be qualified as it is inherently disproportionate. This is because it is impossible to conduct gathering free from any inconvenience to the public in some way. The consideration must rather be whether such nuisance is bearable in a democratic society founded on respect for fundamental freedoms. Thus, unless the participants of the assembly resort to violence 'it is important for public authorities to show a certain degree of tolerance towards peaceful gatherings. ${ }^{, 164}$

This would take us to another related issue regarding the manner restrictions on freedom of assembly (i.e. restrictions related to the manner of participants in the assembly). As noted earlier, peacefulness constitutes a core element of the right to freedom of assembly that bestows the right a protected status. So it is only logical if authorities take measure against assemblies that are imminent threat to peace and security. It is also acceptable if the law bans assemblies and gatherings that incite racial hatred or discrimination which undermines the right of others enshrined in Ethiopian assembly law. ${ }^{165}$

Yet, restrictions related to the manner of participants (i.e. manner restrictions) imposed by administrative officials need to be subjected to proportionality test to avoid unnecessary limitations. Contrary to this principle, some municipalities in Ethiopia seek organizers to secure the peacefulness of assembly in advance as a pre-condition for allowing the gathering to proceed. ${ }^{166}$ Such restriction is too cumbersome on organizers. According to the UN Special Rapporteur on freedom of assembly, what organizers need to demonstrate is their intention to conduct the assembly in a peaceful manner. ${ }^{167}$ Hence, asking them to guarantee the peacefulness in advance does not seem appropriate because it is the state that has the primary duty as well as power to do so. If any duty is to be imposed on organizers it should be that of assisting state security officers in ensuring the smooth running of the assembly.

The state's positive obligation of facilitating assemblies to ensure its peaceful completion is particularly relevant for Ethiopia. This is because; most

\footnotetext{
${ }^{162}$ Report of the Special Rapporteur, supra note 67, para. 41.

${ }^{163}$ Demonstration and Political Meeting Proclamation, supra note 7, art 6(1)

${ }^{164}$ Balçik and Others v. Turkey, ECHR (Application No. 25/02) 29 November 2007 para. 52.

${ }^{165}$ Demonstration and Political Meeting Proclamation, supra note 7, art. 8(1).

166 'Blue Party Demonstration Postponed to 22 September 2013' (Amharic), $<$ http:/hornaffairs.com/am/2013/09/05/ethiopia-blue-party-statement-demonstration/> accessed 31 March 2016.

${ }^{167}$ Report of the Special Rapporteur, supra note 67, para.25-26.
} 
demonstrations are dispersed by the police citing incidence of violence. ${ }^{168}$ Often, few individuals participating in a demonstration will start throwing stones or provoke the crowd towards violent action. It is difficult to know whether these persons are sent by the state itself or not. The usual approach of security personnel is to disperse the assembly immediately irrespective of the magnitude of violence. ${ }^{169}$ Such dispersal orders violate the principle of proportionality. As recommended by the UN Special Rapporteur and Venice Commission of Experts, security personnel should react by singling out provocateurs or those who disturb instead of dispersing the whole assembly. ${ }^{170}$ Such measures will help peaceful participants of the assembly to proceed with their demonstration until the very end.

The Proclamation regulating assemblies in Ethiopia says nothing about the type of weapon that should be utilized by security personnel. However, 'the only circumstance warranting the use of firearms, including during demonstrations, is the imminent threat of death or serious injury. ${ }^{171}$ Hence, security forces should not start firing whenever they see some degree of violence in an undergoing protest. They are rather expected to show more tolerance towards the demonstrators by considering the importance of the right to freedom of assembly and other fundamental rights. As such, what they should do primarily is facilitate the peacefulness of the assembly by picking out those who are utilizing violent means and by using the least harmful but effective force possible. ${ }^{172}$ This would make the measure legitimate, suitable, less intrusive and proportional. However, if life or body is subjected to serious danger, that is about to happen, the use of more force on by the police would be tolerated so long as it meets all the tests of proportionality.

${ }^{168}$ Aaron Maasho 'Ethiopian Police Tear-Gas Crowds Protesting Against Libya Killings' $<$ http://www.reuters.com/article/2015/04/22/us-mideast-crisis-islamicstate-ethiopiaidUSKBN0ND0QW20150422><http://www.reuters.com/video/2015/04/22/ethiopianpolice-tear-gas-crowds-

protest videoId $=363951067 \& \bmod =$ related $\&$ channelName $=$ worldNews $>$ accessed $\quad$ on April 1, 2016.

169 Ibid.

${ }^{170}$ Report of the Special Rapporteur, supra note 67, para. 33.

${ }^{171}$ Id, para. 35.

172 Ibid. 


\section{Public Peace, Public Safety and Public Order Restrictions}

The grounds of public peace, safety and order are considered legitimate for limiting the right to freedom of assembly in many jurisdictions including Ethiopia. However, the application of these grounds needs to be scrutinized properly to prevent their unjustified use in restricting peaceful gatherings. Ethiopian courts lag behind Kenyan courts in this regard. Kenyan courts are becoming active in discharging their constitutional duty 'to hear and determine applications for redress of a denial, violation or infringement of, or threat to, a right or fundamental freedom in the Bill of Rights ${ }^{, 173}$ including the right to freedom of assembly. The following two cases pertaining to freedom of assembly demonstrate how Kenyan courts are utilizing the proportionality test incorporated in the Constitution for reviewing legislative or the executive restrictions imposed on an assembly.

In Eugene Wamalwa $v$. Minister for State for Internal Security, ${ }^{174}$ the applicant Mr. Walmalwa was an elected member of the Kenyan national assembly from the Sabouti constituency who was also interested in running for presidency in the 2012 presidential election. He chose 'Kamukinji Grounds' as a place to officially begin his election campaign. ${ }^{175}$ Subsequently, as per the requirement of the Kenyan Public Order Act, he submitted a notice of intent of organizing such event at 'Kamukunji Grounds' on January 29, 2011 from 10 am to $6 \mathrm{pm} .{ }^{176} \mathrm{He}$ further sought the cooperation of the security personnel to ensure the peaceful undertaking of the political meeting. In the meantime, the applicant continued to make other necessary arrangements such as advertisement and preparation of posters by allocating around 1 Million Kenyan Shillings.

The response of the authorities came fifteen days after the submission of the notice and four days before the undertaking of the planned event. Their decision was to ban the planned political meeting by expressing their fear that "members of an unlawful group known as 'the Mungiki' may attend the meeting and disrupt public order in Nairobi" ${ }^{177}$ They further noted that allowing the political meeting to proceed will also endanger "the rights and fundamental freedoms of others' ${ }^{178}$ Hence, the planned gathering was cancelled.

Upset by the verdict of the police, the applicant approached the High Court in Nairobi alleging the violation of his right to freedom of assembly enshrined under article 37 of the Kenyan Constitution. Before it proceeded to resolving

\footnotetext{
${ }^{173}$ Constitution of Kenya 2010, art. 23(1).

${ }^{174}$ Eugene Wamalwa v Minster for State for Internal Security \& Another [2011] eKLR.

${ }^{175}$ Ibid.

176 Ibid.

${ }^{177}$ Ibid.

${ }^{178}$ Ibid.
} 
the dispute, the court underscored that the right to freedom of assembly could not be restricted in the absence of proportionality considerations laid down in article 24 of the Kenyan supreme law. ${ }^{179}$ More importantly, the court held that the 'state should not be allowed to suppress the freedom of assembly without sufficient and genuine reasons. ${ }^{180}$ It further suggested that if people are denied their right to assemble peacefully and express their view, they might be pushed to resort to other violent means. ${ }^{181}$

It held that the reason provided by the state for cancelling the gathering was not convincing and sufficient. This is because the alleged threat is something which is within the capacity of the state to be averted. The court further stated that the cancellation of the assembly on ground of security 'is tantamount to admitting that the State is incapable of dealing with members of outlawed groups or sects, which is not the case. ${ }^{182}$ From this decision, one can see that the court made an exalting scrutiny to determine whether or not the ground mentioned by the authorities for restricting freedom of assembly is proportional. It particularly shows the failure of the state to meet the necessity element since the security issue could be addressed by less restrictive means than entirely cancelling the assembly thereby causing significant impairment to the right.

In Randu Nzai Ruwa \& two Others $v$. Internal Security Minister, ${ }^{183}$ the applicants were members of Mombasa Republican Council which was declared by the Kenyan government as a criminal organization in accordance with the law regulating organized crime. ${ }^{184}$ The justification provided by the government for taking the measure was that, the council is not registered as an association and it propagates a secessionist agenda contrary to the Kenyan Constitution which proclaims Kenya as 'one indivisible sovereign state. ${ }^{, 185}$ The applicants challenged the decision of the Kenyan government -to dissolve the associationas incompatible with their right to freedom of association and assembly recognized under the Kenyan Constitution.

Before giving its verdict, the court noted that the rights to freedom of association and assembly are indispensable tools for exercising all political rights. ${ }^{186}$ Then, the court went on to determine whether these rights are violated. The court noted that outlawing the association clearly infringes the right to

\footnotetext{
${ }^{179}$ Ibid.

${ }^{180}$ Ibid.

181 Ibid.

182 Ibid.

${ }^{183}$ Randu Nzai Ruwa \& 2 others $v$ Internal Security Minister \& another [2012] eKLR

${ }^{184}$ Ibid.

${ }^{185}$ Constitution of Kenya, supra note 168 , preamble.

${ }^{186}$ Randu Nzai Ruwa \& 2 others v Internal Security, supra note 183.
} 
freedom of assembly and association. ${ }^{187}$ However, since these rights are not absolute, the court went further to assess whether the infringement was justified and reasonable. To arrive at its conclusion, the court referred to the limitation clause of the Constitution which states that any restriction must be 'reasonable and justifiable in an open and democratic society'. ${ }^{188}$ It further underscored the fact that 'democracy is meaningless without tolerance'. ${ }^{189}$ In effect, the court expressed the importance of having tolerance towards hearing different viewpoints including those propagating secession, no matter how much the majority disagrees with them.

The court stated that advocating a secessionist agenda is not in itself a threat to public security or peace so long as the proponents want to achieve their end through peaceful and democratic means. ${ }^{190}$ Since secession is not entertained under Kenya's current constitutional framework, executing such idea needs constitutional amendment which has to follow the necessary procedure. ${ }^{191}$ Yet, promoting such idea alone is not a sufficient reason to deny recognition to the association. The court found that the measure taken by the Kenyan government violates the principle of proportionality since it chose the most restrictive method of dealing with the problem which is a total ban. ${ }^{192}$

Instead of such measures, the court suggested for controlling the activities of the organization through appropriate registration or imposition of criminal liability on members of the association who engage in violence, thereby pursuing a less restrictive means of preventing the feared risk to national security. ${ }^{193}$ This decision is very instructive for countries like Ethiopia which take serious measures against political organizations have different positions on matters stipulated in the FDRE Constitution. As long as individuals or association utilize peaceful means and abide by rules of democracy, they should be allowed to assemble and express ideas even if the views may not be favoured by the current constitutional framework. The public can then be left free to decide whether or not these ideas are acceptable and beneficial without unnecessary involvement of the government.

\footnotetext{
${ }^{187}$ Ibid.

188 Ibid.

${ }^{189}$ Ibid.

${ }^{190}$ Ibid.

${ }^{191}$ Ibid.

192 Ibid.

${ }^{193}$ Ibid.
} 


\section{Decision Making Procedure and Judicial/Administrative Review}

\subsection{Decision Making Procedure}

Most of the problems associated with the notification of assemblies in Ethiopia and the restrictions related to place, time and manner could have easily been resolved had the existing implementing law on freedom of assembly provided for a clear, transparent and inclusive procedure of decision making. The Proclamation governing Peaceful Demonstration and Public Political Meetings rather makes the municipalities or local authorities sole decision makers in the process without the need to involve organizers. ${ }^{194}$ The organizers are not allowed to have a say in the decision making process pertaining to assemblies or restrictions imposed on them as of right. What the law entitles them to is to merely get reasoned decision within the time prescribed by law. ${ }^{195}$ This would make the decision unfair from a procedural point of view since it is made without adequate hearing.

Such practices and procedures are regarded as inappropriate by the Venice Committee of Experts who underscore the importance of ensuring 'that the decision-making and review process is fair and transparent. ${ }^{, 196}$ They contend that the right to freedom of assembly bestows upon the organizers 'full rights to participate in any hearing that takes place', and that such hearing is required if 'limitations or a prohibition are being proposed' ${ }^{197}$ Hence, any decision rendered without involving the organizers of the gathering violates the right to freedom of assembly.

The Committee of Experts has also given an illustration of what constitutes adequate participation in decisions that have a limiting implication for assemblies. These include the right of organizers to be represented by a lawyer in the decision making process and to adduce any evidence that support their claim be it an oral testimony or documentary evidence. ${ }^{198}$ These entitlements are very crucial in the decision making proceedings applicable to assemblies since they ensure the fairness of the process and enhance the possibility of making the right decision. Hence, Ethiopia should consider incorporating these procedures in its law that regulates assemblies.

\footnotetext{
${ }^{194}$ Demonstration and Political Meeting Proclamation, supra note 7, art. 6(2).

${ }^{195}$ Ibid.

${ }^{196}$ OSCE/ODHIR, Opinion on the Draft Law on Meetings, Rallies and Manifestations of Bulgaria, Opinion no. 532 / 2009 (5 June 2009), s.39.

${ }^{197}$ OSCE/ODHIR, Interim Joint Opinion on the Draft Law on Assemblies of the Republic of Armenia by the Venice Commission and OSCE/ODIHR, Opinion no. 596/2010 (22 December 2010) ss.56-57.

${ }^{198}$ Ibid.
} 


\subsection{Judicial or Administrative Review}

Another big lacuna in the Ethiopian law of assemblies is the absence of any administrative or judicial mechanism that reviews the decision of authorities imposing limitations on peaceful demonstrations or political meetings. As far as the Proclamation is concerned, the decision of the municipalities/local administration on accepted notifications or related limitations thereof is final. This is very dangerous because it gives wide discretionary power to authorities to restrict freedom of assembly for whatever reason they think is appropriate since there is no mechanism to hold them accountable. What is striking here is that, despite numerous problems and ineffectiveness of notifications for holding assemblies in Ethiopia, no single application for the review of such decisions has been submitted to courts. What the organizers have done in this respect so far is issuance of statements threatening authorities that they will challenge the decisions in a court of law without actually doing so. ${ }^{199}$ They have also made a few attempts to seek review of such decisions by higher officials of the city administration in an informal manner. ${ }^{200}$

There are other complex issues concerning the role of courts in the interpretation of constitutional rights in Ethiopia including the right to freedom of assembly. On the one hand, the Constitution obliges courts at federal and state levels 'to respect and enforce' fundamental rights and freedoms enshrined in the Constitution. ${ }^{201}$ On the other hand, the Constitution reserves the power of interpreting the 'constitutional disputes' to the House of Federation which represents the Nation and Nationalities of Ethiopia. ${ }^{202}$ This stipulation has been misconceived by members of thejudiciary as precluding courts from entertaining any claim that is principally based on the Constitution. ${ }^{203}$ Hence, judges subscribing to this view have opted to send various cases to the Council of Constitutional Inquiry merely because the Constitution is invoked as the primary legal basis. ${ }^{204}$

Such practice is strongly criticized by some scholars with whom the author agrees. For instance, Takele argues that it is a 'literal' and extended interpretation of the term 'constitutional dispute' that led to the absurd scenario

${ }^{199}$ Blue party Demonstration Postponed to 22 September 2013' (Amharic),

$<$ http://hornaffairs.com/am/2013/09/05/ethiopia-blue-party-statement-demonstration/> accessed 31March 2016

200 Ibid.

${ }^{201}$ FDRE Constitution, supra note 6, art. 13(1).

202 Ibid, art. 83.

${ }^{203}$ Takele Soboka, 'Judicial Referral of Constitutional Disputes in Ethiopia: From Practice to Theory,(2011) 19 African Journal of International and Comparative Law, vol.1 (2011) pp.107-110.

${ }^{204}$ Ibid. 
in which courts have little say in entertaining cases of constitutional importance. ${ }^{205}$ Accordingly, he argues for a restrictive understanding of 'constitutional disputes' which fall under the jurisdiction of the House of Federation. ${ }^{206}$ Such a dispute arises only when the judge on whose bench a constitutional case appears is faced with two or more constitutionally sound interpretations of a certain constitutional clause or article, during which he/she must refer the case to the House of Federation for decision. ${ }^{207}$ As Takele duly notes, such construction ensures harmony among different provisions and gives effect for all.

Not every dispute or controversy raised by the parties over the meaning of a constitutional provision or clause in concrete cases will automatically deprive the court its mandate to entertain the case. If the judges could easily resolve the issues by undertaking a coherent scrutiny of the Constitution, then there is no constitutional controversy and the case ends there. The remedy for the parties will be appeal. It is to be noted that, a constitutional case involves 'constitutional dispute' only when -after due consideration of several issues, the court is of the opinion that there are more than one equally legitimate interpretations of the contested constitutional provision which are in line with its purpose. Such cases involve constitutional controversy and thus fall under the realm of the House of Federation. ${ }^{208}$

This interpretation is in line with the duty of the court (stipulated under the Constitution) to ensure the observance and enforcement of human rights recognized by it including the right to freedom of assembly. It would also make the provision of the Constitution -that provides all people 'the right to bring justiciable matters to court of law'- meaningful. ${ }^{209}$ Hence, decisions restricting freedom of assembly are justiciable matters that could be resolved by courts by examining national and international laws including the Constitution. Furthermore, the duty of the judiciary to enforce human rights recognized by the Constitution should include its obligation to explicate the content of the right to freedom of assembly by referring to treaties ratified by Ethiopia. Such duty should also be extended to determining the appropriateness of restrictions imposed on the right to freedom of assembly (by authorities in Ethiopia) in light of constitutional and international standards. In the absence of such authority, courts cannot legitimately claim to be guardians of fundamental rights enshrined in the Constitution.

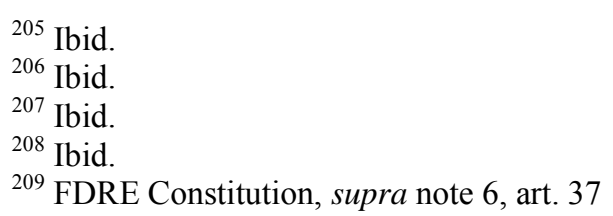


The proclamation establishing federal courts in Ethiopia (i.e. Federal Courts Proclamation No. 25/1996) recognizes the power of courts to enforce fundamental rights incorporated in the Constitution since it gives them material jurisdiction to entertain any case 'arising from the Constitution or federal law'. ${ }^{210}$ Hence, a person claiming the violation of his right to freedom of assembly by arbitrary decision of municipalities could rightly approach courts as his claim is founded on the Constitution. They also have a duty to hear and decide cases. The phrase 'case arising from the federal law' may evoke arguments because the current legal regime applicable for regulation of assemblies was adopted during the transitional period and before the adoption of the present Constitution and the federal structure. However, considering its application at the national level to date, one can regard it as federal law and say that federal courts or regional courts by way of delegation have the right to entertain cases pertaining to the right to freedom of assembly.

The next question would be which kind of courts i.e. administrative or ordinary courts should resolve assembly related cases. On this issue, the practice of other countries shows that some have chosen the former and others the latter as mentioned by the study of the UN Special Rapporteur and Venice Committee experts. ${ }^{211}$ What is important for both bodies is having an opportunity to 'appeal before an independent and impartial court, which should take a decision promptly'. ${ }^{212}$ It is also important to clearly state this right in the law regulating freedom of assembly. Hence, Ethiopia should fill the lacuna in its assembly law by clearly incorporating the right to appeal of organizers of an assembly against any decision they think is an arbitrary restriction of the right to freedom of assembly. The nature of the remedy could be an injunction order or a monetary compensation if civil damage is sustained. Besides, national human rights institutions such as the Ethiopian Human Rights Commission and the Ethiopian Institution of Ombudsman should provide an additional oversight over discretionary administrative decisions pertaining to the right to freedom of assembly since they have the constitutional duty to ensure protection to the right to freedom of assembly.

${ }^{210}$ Federal Courts Proclamation No. 25/1996 2 $2^{\text {nd }}$ year No. 13 Federal Negarit Gazzeta Addis Ababa - $15^{\text {th }}$ February, 1996, art 3(1).

211 'Report of the Special Rapporteur on the Right to Freedom of Peaceful Assembly and of Association', Maina Kiai, A/HRC/20/27 (2012) para.42 \& OSCE/ODIHR, Venice Commission Guidelines on Freedom of Assembly, (2ed Venice, 2010), para.66.

${ }^{212}$ Ibid. 


\section{The Role of Political Will in Safeguarding the Right to Freedom of Assembly}

The preceding sections have shown the gaps in the legal landscape governing the right to freedom of assembly in Ethiopia, problems associated with its implementation and best practices in other jurisdictions. The discussion on these issues serves as a basis for the question as to how we can change this situation by addressing the problems. A very important factor in this regard is political will towards promoting good governance, ensuring rule of law and strengthening democratic institutions. This is very critical because the challenges discussed in the preceding sections are not only attributable to the lacunae in the Constitution and the legislation regulating freedom of assembly. Even the best constitutional and statutory protection afforded to the right to freedom of assembly might not guarantee adequate realization of the right on the ground. In other words, constitutional and legislative gaps have certain contributions but everything cannot be attributed to them. Thus, we need to inquire further and ask other fundamental questions concerning factors that could hinder legislative reform and its implementation.

These questions may include the reason/s for (a) the failure of the government/legislature to enact a law which better safeguards the right to freedom of assembly; (b) unfettered arbitrary power of institutions regulating freedom of assembly without accountability; (c) gross failure of courts (whose independence is formally guaranteed by the Constitution) in discharging their constitutional duty of defending the right to freedom of assembly when it is restricted; (d) the indifference of courts when the right to freedom of assembly is curtailed; (e) the failure of the national human rights institutions (established by the Constitution) to guard against the encroachment of the right; and (f) failure of the media and civil society to play their roles toward ensuring the protection of the right. In sum, there is the need to inquire into the core factor that is preventing democratic institutions recognized by the Constitution such as parliament, courts, national human rights institutions (such as the Ethiopian Human Rights Commission), media's and civil society from defending the protection of fundamental rights including freedom of assembly. As elaborated in the following paragraphs, the main factor which explains many of these questions is the lack of political will of those who hold political power towards good governance, rule of law and functioning of strong democratic institutions.

In his message for the 2013 world human rights day, the UN Secretary General Ban Ki-moon underscored the importance of political will on the part of 
states to ensure the adequate protection of human rights. ${ }^{213}$ Post et al define political will as 'the extent of committed support among key decision makers for a particular policy solution to a particular problem'. ${ }^{214}$ They identify the key decision makers as elected or appointed officials who formulate and make the final policy decision on certain matters. ${ }^{215}$ Depending on the democratic nature of the regime, the decision maker could be a single person or group of persons or shared among the different branches of government in a proportionate manner as envisaged in democratic regimes.

The first element in political will relates to the manner of elections and appointments. Factors like the presidential or parliamentary nature of government, its unitary or federal character, the practice of single party or multiparty system are also crucial in determining key decision makers. ${ }^{216}$ Applying these criteria may shed some light in answering who is holding the key power of making important decisions in Ethiopia. The answer to this question is central to address the role of political will in realizing fundamental rights including the right to freedom of assembly. Constitutionally speaking Ethiopia is a federal state in which power is apportioned between the federal and state governments. ${ }^{217}$ Beside horizontal division, the Constitution also apportions key powers between the legislative, executive and judicial branches of the government. ${ }^{218}$ The Constitution also dictates for a parliamentary democracy with multiple parties. ${ }^{219}$

However, examining the practice may lead to a totally different conclusion. In practice it is often the federal government that makes important decisions for the central government as well as for members of the federation. ${ }^{220}$ Even among the federal government organs, the power relationship is not balanced. Hence, too much power is concentrated in the hands of the executive and the parliament compared to the weak judicial organ. Consequently, the judiciary is unable to exercise a strong oversight over their activities. ${ }^{221}$ With regard to political

${ }^{213}$ United Nations, Secretary-General's Message for 2013

$<$ http://www.un.org/en/events/humanrightsday/2013/sgmessage.shtml $>$ accessed on October 21, 2016

${ }^{214}$ Lori Ann Post et al, 'Defining Political Will' (2010), Politics and Policy p.653.

215 Ibid.

${ }^{216}$ Ibid.

${ }^{217}$ FDRE Constitution, supra note 6, art 1\&46, 50(1).

${ }^{218}$ Id., art 45,

${ }^{219}$ Id., art 50(2)

220 Kalkidan Kassaye, Center-State Relations in the Ethiopian Federal Setup: Towards Coercive Federalism-A Glance From The Federal Practice (LL.M Thesis, Unpublished) School of Law Addis Ababa University, 2010 pp.133-134.

${ }^{221}$ Assefa Fiseha (2011), 'Separation of powers and its implications for the judiciary in Ethiopia' Journal of East African Studies Vol.5 No.4 (2011). 
parties, even if Ethiopia is constitutionally a multi-party state, it has been a single party state de facto for the past 25 years. This has resulted in the blending of the executive branch and the ruling party. Hence, arguably, one can consider the Executive Committee of the ruling political party EPRDF (Ethiopian Peoples Revolutionary Democratic Front) as the key decision maker in present day Ethiopia. ${ }^{222}$

The second element in political will requires the decision makers' understanding 'that a particular issue or condition has reached problem status' and thereupon 'agree on the nature of the problem, and that the problem requires government action'. ${ }^{223}$ For our purpose, the issue which needs adequate government attention or political will is ensuring good governance, observing rule of law and preserving strong democratic institutions in general and protecting the right to freedom of assembly in particular without which sustainable peace and development are unthinkable.

Good governance is a broad concept and it includes a number of elements within its ambit including rule of law and strong democratic institutions. In the general sense it may be construed as 'principles of accountability, participation, transparency and rule of law'. ${ }^{224}$ In the particular sense it means, 'free, fair and frequent election; representative legislature that makes laws and provides oversight; an independent judiciary that interpret laws; ... guarantee of human rights and rule of law; and ...transparent and accountable institutions'.25 Decentralization of power and engaging civil society in decision making process is also an attribute of governance that is good. ${ }^{226}$

The policy decisions made on these critical issues by the key decision makers will have a negative or positive impact on the exercise of the right to freedom of assembly. If they decide to conduct free and fair elections and abide by rule of law as stipulated in the Constitution, a representative parliament will be established. This parliament will be guided by rule of law, not rule by law. This means, the legislature will not rush into adopting whatever law is proposed by the executive or its members. It will rather seriously consider the human right implications of the laws that it adopts, and makes sure that every law it makes will not infringe them in a disproportional manner. ${ }^{227}$ Such policy decisions will

\footnotetext{
${ }^{222}$ Kalkidan, supra note 220, pp.133-134.

${ }^{223}$ Post et al, supra note 214, p. 662.

${ }^{224}$ G.Shabbir Cheema (2005), Building Democratic Institutions Governance Reforms in Developing Countries, Kumarian Press Inc., pp. 5-6.

${ }^{225}$ Ibid.

${ }^{226}$ Ibid.

227 Stefanie Ricarda Roos, The "Rule of Law" as a Requirement for Accession to the European Union, <http://www.kas.de/wf/doc/kas_15604-544-1-30.pdf?090306091009> accessed on October 21, 2016.
} 
better safeguard the right to freedom of assembly and pave the way for the adoption of a right friendly law.

Likewise, if the key decision makers decide to give complete autonomy and operating space for democratic institutions such as courts, national human right institutions, media and civil society, freedom of assembly would be guarded by these actors from arbitrary encroachment. Further, if decision makers make accountability and transparency their number one priority, the institutions regulating freedom of assembly would take extra care not to infringe the right and provide sufficient justifications when they do so. The central question here is whether the key decision maker in Ethiopia i.e. EPRDF regards issues of good governance and democracy as matters worthy of governmental action. Although the party has (on several occasions) stated the gaps in good governance and its willingness to address them, ${ }^{228}$ it has failed to take crucial policy decisions of good governance in a manner that would have ensured better protection of human rights in general and the right to freedom of assembly in particular. Further, it is not clear how good governance, democracy and rule of law are understood by the party.

The third and most important component of political will refers to the commitment of the decision makers. According to Post et al, the heart of political will is commitment on the part of the decision makers 'in supporting a particular policy'. ${ }^{229}$ The central question would be why the leaders of the ruling party who are the key decision makers in Ethiopia are not showing a strong support or commitment to address the serious issue of good governance, rule of law, democratic institutions and respect for human rights including freedom of assembly? This question is important because the ruling party often admits the gaps in good governance and makes pledges to take certain measures to improve the situation, but we do not often see the promised changes in practice.

On this point, Post et al provide two factors which might force the decision makers to be committed to the pledged measure. The first is fear of 'reputational cost' due to which decision makers might be committed to pursue a certain policy measure because failure to bring the promised changes will damage their image in the eyes of the public. ${ }^{230}$ In other words, they will lose credibility in the public and no one will take their pledges seriously. Based on the observation of this author, the ruling party has made so many promises to bring reforms of good governance and rule of law, but has failed to deliver them

\footnotetext{
228 'EPRDF pledges to fulfill responsibility in New Year' 12 September 2016

$<$ http://www.fanabc.com/english/index.php/news/item/6869-eprdf-pledges-to-fulfillresponsibility-in-new-year > accessed: 23 October 2016.

${ }^{229}$ Post et al, supra note 214, p. 663.

${ }^{230}$ Id., p.664.
} 
in a tangible manner. The second factor (identified by Post et al) which forces decision makers to be committed towards a certain measure is the pressure of accountability to the general public. ${ }^{231}$ This presupposes the existence of free and fair election and multi party-democracy. In such systems, if the decision makers fail to show commitment towards certain policy measures that are desired by the public, it will replace them with another party in the next election. This is a strong incentive for decision makers to show strong commitment for their pledges in democratic regimes. But this does not seem to be relevant for Ethiopia because the ruling party has no reasonable fear that it will be replaced by elections at the moment since all relevant institutions for conducting fair elections are under its control or influence. ${ }^{232}$

In spite of these gaps (in the factors that force decision makers towards political will that facilitates good governance, rule of law and strong democratic institutions), the unpredictability of what may transpire in the future with respect to the overwhelming power of the ruling party, long term consideration of peace and development that would accrue from good governance may allure the party to take these reforms. Considering these factors, the ruling party should demonstrate a firm political will to address issues of good governance, rule of law and strong democratic institutions in general which have contributed to the fragile protection of the right to freedom of assembly in Ethiopia.

\section{Conclusion}

The comparative study in this article has identified a number of problems in the Ethiopian legal regime that regulates freedom of assembly. At the constitutional level, the absence of an explicit and full-fledged proportionality requirement in the FDRE Constitution for assessing the acceptability of limitations on freedom of assembly is noted as a problem. Even though the Constitution requires the interpretation of human rights (incorporated in it) to be in line with international treaties, the reference is too generic and proportionality is not immediately evident. This will make the task of enforcement and application unrealistic given the bad track record of the country in democracy, rule of law and human rights protection. Hence, there is good reason to be sceptical about this approach. Instead, an explicit incorporation of proportionality and its constitutive elements in the Constitution (as in the Kenyan Constitution) is a better approach for protecting freedom of assembly rather than merely relying on international treaties as guide for interpretation and conformity.

\footnotetext{
${ }^{231}$ Ibid.

${ }^{232}$ Jason Mosely, 'Ethiopia's elections are just an exercise in controlled political participation', the guardian <https://www.theguardian.com/globaldevelopment/2015/may/22/ethiopia-elections-controlled-political-participation > accessed on October 21, 2016.
} 
Second, at the sub-constitutional level, the existing Ethiopian legislation governing assemblies contains many lacunae. Particularly, its provisions regulating the notification procedure for conducting an assembly and the decision making process are deeply flawed giving too much discretionary power for authorities to do whatever they want. The non-existence of a provision that guarantees the accountability of the authorities through judicial and administrative review has further rendered the right to freedom of assembly defenceless and the authorities unaccountable. Thus, an Ethiopian assembly law that meets the test of proportionality must be enacted without delay to fill significant gaps in the existing law and to make it compatible with international standards set by the UN Special Rapporteur on freedom of assembly and association, UN Human Rights Committee and the Venice Commission of Experts. But for these reforms to happen in the existing legal landscape governing freedom of assembly and be implemented subsequently in appropriate manner, it requires the political will of the ruling party of Ethiopia (EPRDF) which holds the key decision making power toward facilitating the enhancement of good governance and rule of law, and enabling democratic institutions to discharge their constitutional responsibilities.

All these interrelated matters require political will and they have a direct repercussion for in/adequate protection of the right to freedom of assembly. For instance, adopting a good law on freedom of assembly requires a strong democratic institution i.e. parliament which critically debates on proposed bills and ensures its proportionality with regard to the affected right. This in turn depends on free and fair elections and a genuine multi-party democracy that puts fundamental rights at its core which is an imperative element of good governance. Likewise, commitment to rule of law is essential to constrain the parliament from enacting a law that infringes freedom of assembly and to control the executive from applying the law in an improper manner. It also instils transparency, a culture of justification and accountability in their functions.

Moreover, when the parliament and the executive commit infringements in respecting and protecting the right to freedom of assembly, strong democratic institutions such as courts, national human rights bodies, the media and civil societies are expected to intervene and defend the right, and this requires autonomy and operating space. Hence, in the interest of sustainable peace and development, the ruling party should demonstrate genuine commitment to issues of democracy, good governance, rule of law and respect for fundamental rights including freedom of assembly. In the absence of such commitment and political will, it would be naïve to expect the full-fledged protection of the right to freedom of assembly in the Ethiopian law and practice. 